Hispania Sacra, LXII

126, julio-diciembre 2010, 621-659, ISSN: 0018-215-X

\title{
EL ROSARIO Y SUS COFRADÍAS EN ANDALUCÍA. UNA APROXIMACIÓN HISTÓRICA
}

\author{
POR \\ Carlos José Romero Mensaque \\ U.N.E.D. Centro Asociado de Sevilla
}

\begin{abstract}
RESUMEN
El Rosario en Andalucía constituye mucho más que la devoción mariana por antonomasia o la iconografía de la Virgen más repetida en los templos de sus pueblos y ciudades. Constituye todo una estructura socio-religiosa que marca la existencia de las personas desde el siglo XVI hasta la primera mitad del siglo XX y que todavía pervive en muchas de sus manifestaciones. El Rosario nace como oración vocal y mental que se concreta en un instrumento de cuentas, pero que pronto se hace estética palpable en las imágenes de la Virgen con esta advocación, en las cofradías y hermandades, pero sobre todo es un fenómeno específico de la religiosidad popular desde fines del siglo XVII con el uso de los Rosarios públicos o callejeros
\end{abstract}

PALABRAS CLAVE: Rosario, Andalucía, rosarios públicos, cofradías del Rosario.

\section{THE ROSARY AND THE CONFRATERNITIES IN ANDALUSIA. A HISTORICAL APPROACH}

\begin{abstract}
The Rosario in Andalusia is much more than the par Marian devotion or the iconography of the Virgin repeated in most temples in their villages and towns. It is primarily a socio-religious structure that marks the existence of people from the sixteenth century until the first half of the twentieth century and still survives in many of its manifestations. The Rosary was born as a vocal and mental prayer is expressed in an audit, but that soon becomes palpable aesthetic in the images of the Virgin with this dedication, in the guilds and brotherhoods, but it was a specific phenomenon of religiosity popular since the late seventeenth century with the use of public or street Rosaries
\end{abstract}


KEY WORDS: Rosary, Andalusia, public Rosaries, confraternities of the Rosario.

Recibido/Received 27-10-2008

Aceptado/Accepted 10-12-2009

El Rosario en Andalucía constituye la devoción mariana por antonomasia o la iconografía de la Virgen más repetida en los templos de sus pueblos y ciudades. Pero es mucho más que eso. Constituye toda una estructura socioreligiosa que marca la existencia de las personas desde el siglo XVI hasta la primera mitad del siglo XX y todavía pervive en muchas de sus manifestaciones.

El Rosario nace como oración vocal y mental, se concreta en un instrumento de cuentas, que pronto se hace estética palpable en las imágenes de la Virgen con esta advocación, en las cofradías y hermandades. Es sobre todo un fenómeno específico de la religiosidad popular desde fines del siglo XVII con la celebración de los Rosarios públicos o callejeros. Gracias al Rosario público, el rezo, que aparece ya estructurado a fines del siglo XV y alcanza su primera gran difusión en la segunda mitad del XVI a través de los Dominicos, se convierte en una devoción que traspasa los umbrales de la tutela clerical y adquiere connotaciones genuinas de raíz popular.

En este proceso fueron fundamentales las hermandades y cofradías en una muy variada tipología.

Este artículo tiene una base documental en Sevilla y su provincia, por ser el ámbito principal de mis investigaciones, ${ }^{1}$ aunque he tenido acceso a una amplia referencia documental y bibliográfica para toda Andalucía. Apuntaré incluso noticias sobre Hispanoamérica, concretamente la ciudad de Córdoba (Argentina) con un aporte andaluz indudable, aunque poco conocido.

Baste indicar que el fenómeno tiene sus raíces en la Plena Edad Media y en un ámbito mixto entre monjes cartujos y frailes dominicos principalmente. Se consolida y adquiere su conformación y primera expansión en la segunda mitad del siglo XV con las figuras de los dominicos Alano de la Roca, Jacobo Sprenger y el español Juan Agustín, coincidiendo con la fundación de las Cofradías del Rosario (Colonia, 1475), que muy pronto se asentaron en los cenobios do-

\footnotetext{
${ }^{1}$ Sobre el Rosario en Sevilla publiqué completa mi tesis doctoral El Rosario en Sevilla: devoción, rosarios públicos y hermandades (siglos XV-XXI), Sevilla, Fiestas Mayores, 2004, obra de referencia del estado de las investigaciones del fenómeno rosariano en la capital. Sobre la provincia acabo de publicar El Rosario en la provincia de Sevilla: religiosidad, cofradías y hermandades, Sevilla, Diputación, 2010.
}

Hispania Sacra, LXII

126, julio-diciembre 2010, 621-659, ISSN: 0018-215-X 
minicos andaluces. Documentalmente la primera es la de San Pablo en Sevilla fundada por Fray Alonso de Hojeda (1479-1481).2

La gran difusión se produce tras la victoria de Lepanto (1571), siendo Córdoba diócesis muy adelantada y el real convento de San Pablo centro principalísimo de expansión devocional. Cuando se generaliza, comienza el rosario por las calles, a fines del XVII en la ciudad de Sevilla, a partir de las predicaciones del dominico Fray Pedro de Santa María de Ulloa. Es muy parecido a lo que pasa en Málaga. En ambos casos tras unas misiones populares promovidas por los obispos. En Málaga, lo era el dominico Fray Alonso de Santo Tomás.

Fue el capuchino Fray Pablo de Cádiz, en unas misiones promovidas por el obispo Barcia, quien organizó el Rosario en la capital gaditana con sus insignias: el Simpecado propio y los faroles, o por mejor decir, las farolas o «marías» de enorme tamaño que lo acompañaban como elemento casi litúrgico, además de las coplas, sobre todo las de la aurora. Fue esta última una expresión genuina y de enorme interés principalmente en la provincia de Córdoba.

Desde el siglo XIX el Rosario público se limita progresivamente a las procesiones de la aurora los días festivos. La devoción va centrándose en la imagen de la Virgen de esta advocación. Se le rinde culto y se la procesiona en su festividad. Se la proclama patrona de muchas poblaciones y sus tallas se encuentran en la mayor parte de las iglesias.

Hay pocos estudios específicos. Para Granada, Miguel López-Guadalupe ha recopilado diversos datos sobre cofradías rosarianas en una interesante síntesis. ${ }^{3}$ Córdoba cuenta con los excelentes artículos de Aranda Doncel, autor asimismo de una monografía sobre la corporación rosariana de la Virgen del Socorro. ${ }^{4}$ En Málaga, los trabajos de Rafael Retana sobre las hermanda-

\footnotetext{
2 Sobre las primeras cofradías dominicas europeas existe diversa bibliografía extranjera. Puede citarse como ejemplos clásicos: H. D. SAFFREY, «La fondation de la confrérie du Rosaire à Cologne en 1475, histoire et iconographie», dans Humanisme et imagerie aux XVe et XVIe siècles, París, Librarie Philosophique J. Vrin, 2003 y S. ORLANDi, Libro del Rosario della Gloriosa Vergine María, Roma, Centro Domenicano Rosariano, 1965. Sobre la Cofradía de San Pablo de Sevilla y su fundación en 1481, vid.el Manuscrito de Fray Francisco RAmírez de Solórzano, Historia del Santo y Real Convento de San Pablo de Sevilla, de la Orden del Glorioso Patriarca Santo Domingo [...] que se halla en los fondos documentales del Convento de Santo Tomás de Sevilla, fol 40 vto. Igualmente, J. SAgredo, O. P., La Hermandad del Rosario del convento de Regina Angelorum del Orden de Predicadores y la Real Maestranza de Caballería, Sevilla, 1923, P. 13. Los primeros documentos de la cofradía datan de 1492.

${ }^{3}$ Cfr. «Expansión de las cofradías del Rosario en la diócesis de Granada en la época moderna», en H. Paz Castaño y C. Romero Mensaque (Coords.), Congreso Internacional del Rosario. Actas, Sevi1la, 2004, PP. 379-389.

${ }^{4}$ Cfr. «Los dominicos y la difusión de las cofradías del Rosario en la diócesis de Córdoba durante los siglos XVI y XVII», en Juan Aranda Doncel, Las Advocaciones Marianas de Gloria. Actas del I Congreso Nacional, Córdoba, 2002, tomo 1, PP. 75-102., «Las hermandades y los Rosarios públicos en la diócesis de Córdoba durante la Edad Media», en H. PaZ Castaño y C. Romero MensaQue
} 
des. ${ }^{5}$ Hipólito Sancho de Sopranis, Ángel Mozo y, más recientemente Fray Vicente Díaz han estudiado tanto la imagen de la Virgen del Rosario de Cádiz como su Cofradía. También Francisco Espinosa de los Monteros ha investigado recientemente los Rosarios públicos en la capital y provincia. ${ }^{6}$ En Huelva existen publicaciones recientes sobre el Rosario. Lo he estudiado en la Sierra de Aracena y la Cuenca Minera. Para Almonte, el trabajo de Padilla Díaz de la Serna. ${ }^{7}$ Hay una síntesis sobre la religiosidad popular en Jaén durante la época moderna de Coronas Tejada, y sobre las cofradías, de López Molina. ${ }^{8}$ Finalmente, en Almería, el trabajo inédito de José Manuel Navarro Ojeda, La devoción del Rosario en la diócesis de Almería y la monografía general sobre hermandades de Gil Albarracín. ${ }^{9}$ Casi todos los estudios se centran en los siglos XVI al XVIII.

\section{EL ROSARIO, SU INFLUENCIA EN LA RELIGIOSIDAD BARROCA Y LA IMPORTANCIA DE LAS MSIONES}

La religiosidad popular adquiere en Sevilla auténtica carta de naturaleza en torno a la segunda mitad del siglo XVII en ocasión del dramático episodio de la

(Coords.), 363-376. Por último la monografía La devoción a la Virgen del Socorro en Córdoba durante los siglos XVII al XX, Córdoba, Cajasur, 1998.

${ }^{5} \mathrm{Cfr}$ «Apuntes para la historia de una devoción mariana en Málaga: el Rosario» en La Saeta, $\mathrm{n}^{\circ} 24$, Málaga, noviembre 1999., «Fray Alonso de Santo Tomás y su influencia en los orígenes de los rosarios callejeros de Málaga», en Herminio Paz Castaño y Carlos Romero Mensaque, (coords.) 391-397 y «Las hermandades del Rosario en la Málaga del siglo XVIII», en Historia devocional en la Málaga del siglo XVIII. La Antigua Hermandad de Nuestra Señora de los Remedios de la parroquia de los Santos Mártires, Málaga, 2007, pp. 19-41.

${ }^{6}$ Hipólito Sancho de Sopranis, Nuestra Señora del Rosario, Patrona de Cádiz y de la Carrera de Indias y su convento de Padres Predicadores. Ensayo histórico documentado, Cádiz, 1927. Ángel Mozo Polo, «Presencia de V siglos del Rosario en Cádiz», en Cincuentenario, Cádiz, 4 de mayo de 1947-1997, Cádiz, 1997, pp. 15-46. Vicente Díaz RodríGuez, OP, Negros y frailes en el Cádiz del siglo XVII, Salamanca, San Esteban, 2009; Francisco Espinosa DE los Monteros SÁncheZ, «Historia de los Rosarios públicos en Cádiz», en H. Paz Castaño y C. Romero Mensaque, (coords.) 419-424.

${ }^{7}$ En el caso de Huelva, recientemente he publicado un pequeño artículo sobre la Sierra de Aracena y la cuenca minera en «Religiosidad popular y tradición en la Sierra de Aracena: el fenómeno rosariano en la época moderna y contemporánea», en Anuario de Investigaciones Hespérides, n 13-14 (20052006), Cádiz, 2006, pp. 161-177. Santiago Padilla ha realizado un pormenorizado estudio sobre Almonte en «La devoción del Santo Rosario en Almonte y su relación con la devoción a la Stma. Virgen del Rocío», en Testimonios históricos de la devoción de los almonteños a la Madre de Dios. Devociones, imágenes, ritos y cofradías marianas en Almonte, Almonte, 2006, pp. 25-82.

${ }^{8}$ Una síntesis de la religiosidad popular en la época moderna en Luis CoRONAS TEJADA, «Manifestaciones de la religiosidad popular en Jaén durante la Edad Moderna», en Juan ARANDA Doncel (Coord) Congreso de Religiosidad Popular en Andalucía, Cabra, 1994, pp. 141-150 o bien Manuel LóPEZ MolinA, «De las antiguas cofradías giennenses de Gloria: siglos XVI-XX», en Juan ARANDA DonCEL, Las Advocaciones Marianas de Gloria. Actas del I Congreso Nacional, Córdoba, 2002, tomo 1, pp. 189-200.

${ }^{9}$ Cofradías y Hermandades en la Almería moderna, Almería, 1997.

Hispania Sacra, LXII

126, julio-diciembre 2010, 621-659, ISSN: 0018-215-X 
Peste de 1649. Murió más de la mitad de la población. Desde entonces, el esquema de cristiandad barroca adquirió unas características propias en la ciudad y sirvió de modelo para muchas otras poblaciones.

Hay un incremento de las Misiones cuaresmales en un clima especialmente dramático, lleno de temor a un Dios que inflige todo el peso de su poder a quienes se desvían de sus normas y se dejan llevar por la tentación de lo material, efímero y perecedero. El pueblo revive todo el drama de aquella epidemia. En estas Misiones se transmite un fortísimo sentimiento de culpa, una tensión a veces irracional que deriva en llantos colectivos, gritos, desmayos...

Los misioneros diseñan un esquema catequético, con un montaje claramente teatral, para mover a conversión. Se promueven procesiones con la imagen de un Crucifijo, sermones espectaculares como el de la Muerte, confesiones...

Se va perfilando también una religiosidad distinta en ese pueblo que asiste y se emociona con estas Misiones, con elementos propios. El caso más patente se refiere al rezo del Santo Rosario, que fomentan extraordinariamente los misioneros, como devoción individual y comunitaria. Hay una especie de absolutización rosariana, consecuencia de una deficiente «cultura» religiosa. El Rosario aparece como una síntesis vital de fe y práctica devocional.

Las Cofradías del Rosario estaban erigidas en los cenobios dominicos y en muchos pueblos de la provincia desde los años finales del XV y gozaban de grandes prerrogativas espirituales concedidas por los Papas a cofrades vivos y difuntos.

Junto a Sevilla, Granada parece ser la otra gran capital donde se erige la Archicofradía del Rosario a fines del siglo XV, en ocasión de la conquista de los Reyes Católicos. Falta documentación sobre Granada y Córdoba. En esta última capital existe la Cofradía de San Pablo. Puede pensarse que sea de la misma antigüedad que la de Sevilla. Quizás sea también temprana la cofradía en el cenobio dominico de Málaga, fundado en 1495. Otro gran centro rosariano fue Jerez, donde se documenta una Cofradía en $1525 .{ }^{10}$ La Cofradía de los Negros de Cádiz y la de la Instinción en Almería datan probablemente de fines del XVI. De la misma época constan diversas cofradías de Jaén capital y su provincia como Cambil, Noalejo o Mancha Real

La gran difusión rosariana en Andalucía y la consiguiente fundación de cofradías tienen su primer gran momento en la segunda mitad del siglo XVI, sobre todo a partir de Lepanto (1571). El rezo y la devoción son respaldados oficialmente por la Santa Sede y la Orden de Predicadores, que adquiere un

10 Sobre esta Cofradía, Sancho de Sopranis publicó en la revista «Santísimo Rosario» cuatro pequeños artículos entre enero y abril de 1918. 
protagonismo absoluto en su propagación a través de sus conventos y con las misiones de frailes especialmente comisionados por el Maestro General para fundar en las distintas parroquias, con el apoyo de muchos prelados.

El Rosario es paradigma de la religiosidad popular andaluza desde la segunda mitad del siglo XVII. Tras el fallecimiento en Sevilla y en olor de santidad del más importante promotor de estas Misiones, el dominico gallego Pedro de Santa María de Ulloa, hay un movimiento espontáneo de crear un esquema permanente de religiosidad que reviva de una manera cercana y cotidiana el clima de las Misiones y el medio más adecuado será el Rosario público o callejero en 1690.

Esta procesión hace salir a lo sagrado del templo, no requiere necesariamente una imagen bendita, pues es el propio grupo de devotos quienes testimonian la presencia de Cristo y María y, sobre todo, el pueblo se siente actor de la religión.

Las Misiones crean un poso espiritual que permanece en asociaciones o congregaciones de marcado carácter penitencial y de culto interno en relación con el Rosario. No es casual que las Misiones jesuíticas de 1669, 1672 y 1679, dirigidas en Sevilla por el padre Tirso González, las organizaran en las parroquias en que predicaban. En las de San Bartolomé, Salvador, San Vicente, Santa Ana surgieron con inusitada fuerza. ${ }^{11}$

En Málaga se registró un dramático terremoto en 1680. Quiso su obispo, el dominico Fray Alonso de Santo Tomás, que se predicaran misiones. Se fomentó extraordinariamente la devoción del Santo Rosario y sus cofradías, tal como se lee en las disposiciones sinodales. ${ }^{12}$

Lo mismo hizo en Cádiz el obispo José de Barcia y Zambrana. Predicó la misión el capuchino Fray Pablo de Cádiz en 1691.

\section{EL ROSARIO PÚBLICO}

\subsection{Los precedentes del fenómeno y los primeros rosarios en Sevilla}

El Rosario público, surgido el año 1690 en Sevilla, tiene precedentes en el siglo XVI en las cofradías dominicas que celebraban los primeros domingos de mes procesiones claustrales con la imagen titular y a las que asistían los cofra-

\footnotetext{
11 Vid. más información en la obra monumental de Elías ReYero, Misiones del P. Tirso González (1665-1686). Santiago de Compostela, 1913

${ }_{12}$ Rafael Retana Rojano, «Fray Alonso de Santo Tomás y su influencia en los orígenes de los rosarios callejeros de Málaga», op. cit.

Hispania Sacra, LXII

126, julio-diciembre 2010, 621-659, ISSN: 0018-215-X
} 
des con rosarios en las manos. Celebraba otra solemne por la calle el primer domingo de octubre, la Procesión de la Batalla Naval.

Las Misiones populares se iniciaban con una multitudinaria procesión en el acto de contrición previo. En pos de un Crucifijo portado por los misioneros, iban las gentes rezando con rosarios y cruces en las manos. Los niños cantaban por las calles coplas religiosas. Estas procesiones, como hemos visto, aparecen en las Misiones jesuíticas del siglo XVII.

El marianismo de la ciudad, reforzado por la cuestión concepcionista, explica la aparición de los simpecados y coplas, sobre todo las de Miguel Cid a la Inmaculada... se van incorporando a las expresiones de piedad mariana del pueblo. Salían del convento franciscano de San Diego de Alcalá sendas procesiones precedidas por fray Juan de Prado que portaba un Estandarte con la efigie de la Inmaculada. ${ }^{13}$

La devoción inmaculista se integró en el Rosario y éste quedó marcado por aquella en su expresión más popular. La «Cuestión Concepcionista», motivada sólo en parte por una grave imprudencia de la Orden de Predicadores, en lugar de mermar la devoción y rezo del Rosario, creció y eso prueba su popularidad. Se revitalizó. Sus promotores, nada proclives a los dominicos, recitaban, tras cada avemaría, «Alabado sea el Santísimo Sacramento y la Inmaculada Concepción de la Virgen Nuestra Señora, sin mancha de pecado original». Lo vemos en un grabado que acompaña las célebres coplas de Miguel Cid, coetáneo a su publicación.

En la historiografía eclesiástica pueden rastrearse otros precedentes fuera de España. En Italia existe amplia tradición todavía por investigar. El cronista sevillano Martín de Braones recoge el tenor de un impreso italiano que refiere una procesión del rosario en Roma en la primera mitad del XVII:

«Escribe el M.R.P.M. Fr. Ambrosio Brandi en su triunfo del Rosario, hecho en Roma el año del Señor 1625, con la ocasión del Santo Iubileo que el Sumo Pontífice Urbano VIII, estando muy edificado y satisfecho de los padres de la Minerva de Roma por aver introducido este divino exercicio en su iglesia de hazer rezar el Rosario a coros al pueblo romano, donde concurría casi toda la ciudad y un gran número de señores eminentísimos cardenales, quiere Su Santidad favorecer esta iglesia con concederle muchas vezes el santo Iubileo: porque la primera vez concedió a todos los cofrades y cofradesas del Rosario el Santo Iubileo la dominica de septuagésima para los que confessados, y comulgados visitaren las quatro Iglesias principales, vna vez en processión, y otras tres vezes con su Comunidad: de donde con el cuydado del famoso Capitán, y Apóstol del Rosa-

13 Manuel SERrano Ortega, Glorias sevillanas. Noticia histórica de la devoción y culto que la MN y ML ciudad de Sevilla ha profesado a la Inmaculada Concepción... Sevilla, 1893, p. 249. Este Estandarte se encuentra en la actualidad en el convento de San Francisco de Santiago de Compostela y es el que salió en 1616 en una solemnísima procesión inmaculista. 
rio, el P.M. Fr. Timoteo Riccio, se ordenó aquella estupenda Procesión que ha pasmado no sólo a Roma que la vio, sino también a todo el mundo que lo ha sabido: porque se juntó el número de setenta mil, divididos en quinze esquadras, a honra de los quinze Misterios del Saníissimo Rosario, y todos cantavan el Rosario a coros, y pareció tan bien a los ojos del Sumo Pontífice que, viéndola de lexos, pasmado del hermoso exercicio de María bien ordenado, advirtiendo que faltava el Capitán General quiso suplir su falta y dixo con dulces y humildes palabras: vamos también nosotros a visitar las iglesias con esta procesión, porque también nosotros somos de la compañía del Rosario; y se vio muchas vezes el dicho Pontífice ir acompañando la dicha Procesión con gran gusto. Hasta aquí el citado autor». 14

Muy claramente aparecen los rosarios públicos en las colonias españolas en América y también Filipinas al menos desde los comienzos de la segunda mitad del siglo XVII. Veamos algunos ejemplos.

En Ciudad de Méjico desde el Convento de Santo Domingo en 1650. En 2 de octubre de este año, según refiere el cronista coetáneo Martín de Guijo, se dio principio en el convento de Santo Domingo de esta ciudad la devoción del Rosario rezado de rodillas promovida por dos clérigos y se organizó una solemne procesión con la imagen de la Virgen del Rosario, acompañada del rezo a voces del Rosario por sus devotos. Igualmente la Nochebuena de este año «[...] se juntaron mulatos, negros, mestizos e indios en las cruces de esta ciudad y a voces rezaban el Rosario de Nuestra Señora, de rodillas y por las calles iban haciendo lo mismo muchachos en cuadrilla mucha cantidad de ellos y personas de todas edades, y hubo cuadrillas por las calles gobernadas de algunos sacerdotes que los seguían». ${ }^{15}$

No obstante, debido principalmente a diversos abusos, en 15 de enero del año siguiente fueron prohibidos estos Rosarios callejeros por el Ordinario diocesano, circunscribiéndose el rezo a las iglesias y las casas. ${ }^{16}$

El Rosario público se constituyó en uso ordinario de los misioneros dominicos en Nueva España, fomentando su uso también entre los indígenas. En Oa-

${ }^{14}$ Calisto de Missanello, O.P., Regola e constitutioni, esserciti espirituali e ceremonie da osservarsi dalle congregationi Compagnie del Rosario, Napoli, F. Savio, 1646, parte 8, razón 15. Existe un ejemplar en la Biblioteca Nacional de Madrid, que he podido consultar. El original es italiano y la traducción, muy correcta, es de Martín de Braones en su opúsculo sobre los primeros Rosarios de Sevilla, de los que fue el cronista de referencia. Cfr. Copia de un papel remitido a esta ciudad de Valencia, en que se da segunda noticia del grande aumento a que ha llegado en la Muy Noble y muy Leal Ciudad de Sevilla la devoción del Santísimo Rosario de la Virgen María, N. Señora, Valencia, Imprenta de Jaime Bordazar, 1691. Se ha utilizado el ejemplar sito en la Biblioteca Valenciana «San Miguel de los Reyes», a cuyos responsables agradezco su colaboración, especialmente a Nuria Soler.

${ }^{15}$ Cfr. «Diario de sucesos notables escrito por el licenciado D. Gregorio Martín de Guijo, y comprende los años de 1648 a 1664», en Documentos para la historia de Méjico, 1853, tomo 1, pp. 146 y 161.

16 Íbidem, p. 167.

Hispania Sacra, LXII

126, julio-diciembre 2010, 621-659, ISSN: 0018-215-X 
xaca, tanto en Jalapa como Tehuantepec afirma Burgoa en 1674: [...] y lo que más es de estimar en este pueblo y en Tehuantepec es la devoción del Santísimo Rosario, teniendo cada barrio su capilla de cantores con todos sus ministriles de bajón, corneta y dulzaina y excelentes voces escogidas y niñas doncellas enseñadas, que saben de memoria todos los quince misterios a dos y tres cuartetas cada uno en metro poético, traducidos en su lengua, por los religiosos y letanías de Nuestra Señora y en dando el Ave María se empiezan a recoger hombres y mujeres de cada barrio en su ermita y juntos todos a las siete de la noche empiezan dos niñas que tienen señaladas de mejores voces el Per signum Crucis en alto todo y va respondiendo toda la capilla a cada verso, y prosiguen los misterios con tanta armonía que parecen coros de ángeles, todos hincados de rodillas mientras duran los versos, y a las oraciones del padrenuestro y ave maría se levantan y empiezan a andar todos en procesión y las niñas guiando para la iglesia principal, y en acabando un decenario vuelven a arrodillarse donde las coge y las niñas prosiguen en su tono los versos del Misterio que se sigue, y con este estilo prosiguen hasta la puerta de la iglesia, donde, de rodillas, acaban el Rosario y sus ofrecimiento, y tras de él la letanía de la mesma manera y vuelven a su ermita, donde hacen oración, y de allí se van a sus casas y cada barrio hace lo mesmo y esto los lunes, miércoles y viernes [...]. ${ }^{17}$

También en la nación zapoteca los indios rezaban el rosario a coros por las calles. ${ }^{18}$

Parece evidente que el uso era bien conocido en la Orden por los padres misioneros y los que debían formarse como tales en el Convento de San Pablo de Sevilla, amén de que en la cotidiana convivencia, los frailes compartieran sus experiencias en las tierras de misión.

En este contexto aparece en Sevilla en 1687 la figura de Fray Pedro de Santa María de Ulloa, conocido como «el apóstol del Rosario» con una amplísima trayectoria misional en Hispanoamérica y que ciertamente habría de conocer e incluso fomentar estas prácticas rosarianas, aunque no nos conste documentalmente que lo hiciera expresamente en Sevilla, si bien no es descartable. ${ }^{19}$

En el ámbito andaluz y sevillano existen algunos casos aparentemente identificados como tales rosarios anteriores a 1680 en Málaga, según el cronista lo-

\footnotetext{
${ }^{17}$ Francisco de BurgoA, Geografica Descripción de la parte septentrional del polo ártico de la América, México, 1674, tomo 2, pp. 328-329.

${ }_{18}$ Idem., tomo 1, p. 417.

${ }_{19}$ Sobre la figura y obra apostólica del padre Ulloa, vid. prólogo de la obra autógrafa Arco iris de paz, Barcelona 1765 y que redactó Fray Diego de la Llana. Una síntesis biográfica en ARANDA, Gabriel de, S.I., Vida del siervo de Dios, exemplar de sacerdotes el venerable padre Fernando de Contreras, Sevilla, 1692, pp. 891-896.
} 
cal Medina Conde,,$^{20}$ en fechas muy significativas para la ciudad, en que se intensificaron las Misiones, pero también en Utrera (Sevilla), donde parece documentarse estos Rosarios antes de 1686. Joaquín González Moreno así lo afirma al referirse a la Hermandad de la Divina Pastora, ${ }^{21}$ aunque no aporte documentación. He consultado en el Archivo de Protocolos de Sevilla un convenio entre la Hermandad de Jesús Nazareno y de la Divina Pastora de 1716 donde se afirma: «[...] dixeron que por quanto en el año pasado de mill seiscientos y ochenta y seis o siete tubo principio en esta iglesia (ermita de S. Bartolomé) de salir de noche resando el Rosario a imitación del que se avía fundado en la casa hospital de la Santa Misericordia de esta villa [...]».22

Documentación posterior de la Hermandad del Rosario de la Misericordia insiste en estas fechas, pero las supedita a la predicación pionera del padre Ulloa en Sevilla y como fue D. Juan Fernández de Henestrosa, marqués de la Cueva del Rey, el que comenzó esta práctica en Utrera formando un cortejo con niños y criados, el que posteriormente asentó en el hospital de la Misericordia, donde lo halló el capuchino Fray Feliciano de Sevilla y se procedió a su erección canónica como hermandad de Jesús, María y José en 1691.23

Estos primeros rosarios sevillanos eran muy espontáneos. Podemos definirlos como trasuntos de los rezos comunitarios que dirigía Ulloa en el convento de San Pablo cada día a la aurora, mediodía y prima noche. El rosario regía la vida cotidiana.

El primer Rosario público, sin insignia alguna, fue el de los feligreses de la parroquia de San Bartolomé un 17 de junio de 1690 y en torno a la imagen de Nuestra Señora de la Alegría, patrona del barrio, cuya hermandad, posteriormente, se encargaría de la organización de los Rosarios. La salida coincidió con la celebración de los solemnes funerales por el padre Ulloa en San Pablo.

${ }^{20}$ Rafael Retana Rojano, «Fray Alonso de Santo Tomás y su influencia en los orígenes de los Rosarios Públicos en Málaga», en H. Paz Castaño y C. Romero Mensaque, 391-92. Este analista afirma que, según documentos del archivo general del obispados (desaparecidos posiblemente en la Guerra Civil) la Congregación del Rosario de la Aurora fue anterior al año 1680 y fue su fundador Juan Sánchez, maestro de escuela y tercero dominico que sacaba este rosario con sus alumnos de madrugada. No obstante carecemos de las fuentes originales en que se basa.

${ }^{21}$ Cfr Utrera en el siglo XVIII, Utrera, 1995, p. 99.

22 Archivo de Protocolos Notariales de Sevilla, legajo 3153 PB. En él aparecen diversos documentos de 1716, entre ellos un convenio entre la Hermandad de Jesús Nazareno y de la Divina Pastora, del que faltan varios folios (del 55 al 58) curiosamente donde debía encontrarse el dato. Gracias a D. Antonio Cabrera, he conseguido fotocopia de algunos de estos folios «perdidos» que se hallaban en un domicilio particular

${ }^{23}$ Archivo General del Arzobispado de Sevilla, Serie Hermandades, legajo 191. Hay un informe muy interesante de dos de julio de 1718. Este rosario, ya de hombres, salía a prima noche y madrugada. En unos autos de 1743 se afirma la antigüedad del primer rosario en 1687. Cfr. Legajo 193.

Hispania Sacra, LXII

126, julio-diciembre 2010, 621-659, ISSN: 0018-215-X 
En esta parroquia había predicado el dominico la Cuaresma anterior. Como hizo en su convento, instituyó el rezo del Rosario todos los días a la aurora, mediodía y prima noche. Se mantuvo tras su muerte. ${ }^{24}$ Fue el comienzo de toda una expansión por las parroquias, iglesias, conventos y hermandades en poco tiempo y pronto obligó a una mínima organización de los propios devotos y del clero secular y regular.

Los Rosarios salían a diario a prima noche a fin de rezar el último tercio de la oración, pero los festivos las parroquias solían organizarlo por las tardes, muy temprano, casi a mediodía. Parecía una procesión especial, con muchos feligreses y con estaciones en algunas iglesias, conventos o la Catedral. Era ocasión de ceremonias festivas de recibimientos que pronto se convertirán en tradicionales y crearán una liturgia muy expresiva de las relaciones entre los Rosarios. Muy pronto, el rezo tres veces al día, aurora, mediodía y prima noche, posibilitará una nueva salida por las calles en la madrugada, tras el rezo primero de la aurora en la iglesia, los devotos salen a entonar las avemarías, volviendo a la hora del alba a celebrar la eucaristía.

El testimonio hasta ahora inédito de Martín Braones, el gran cronista de los primeros Rosarios en Sevilla, ${ }^{25}$ afirma que este ejercicio de la Aurora lo iniciaron los hermanos de la Orden Tercera de Santo Domingo del convento de San Pablo. Hacían estación a la Catedral: «No contenta la devoción de los hermanos de San Pablo con rezarle tres veces al día, y de noche por las calles, después que rezan el primer tercio a la aurora, inmediatamente salen por las calles en la forma dicha, dando la alvorada a las almas vigilantes, y avisando deseen el sueño a las que lo tomaron por alivio de sus virtuosas tareas, rematando su estación en la S. Iglesia Catedral...».

Este Rosario tenía esta particularidad respecto al de Prima: tras recogerse la procesión en su sede, los cofrades asistían a la misa denominada «de alba». Esto indica un signo de estabilidad en la congregación organizadora en cuanto a concurso de devotos y cofrades y a ingresos económicos para sufragar los gastos procesionales y estipendio del capellán. Supone un medio de comunión con la religiosidad oficial al favorecer la participación de los cofrades en la máxima expresión de la liturgia que es la eucaristía. Pero aún hay más. Estas misas de alba facilitaban el cumplimiento del precepto de oír misa a los trabajadores del campo que comenzaban muy pronto su jornada laboral... y también a los po-

\footnotetext{
${ }^{24}$ Son varias fuentes coetáneas las que confirman la primacía de la parroquia de San Bartolomé y el vigor y entusiasmo de feligreses y cofrades en tono al rezo y a su común devoción a la Virgen de la Alegría, que era la imagen de referencia de este primer cortejo, así como la espontaneidad de unos cortejos en los que no figuraba insignia alguna salvo faroles o hachas encendidas. Cfr. sobre todo, la crónica de Martín de Braones, que cito en la nota siguiente.

${ }^{25}$ Copia de un papel remitido a esta ciudad de Valencia [...].
} 
bres y marginados de la sociedad, que a veces no se atrevían por su indumentaria a participar en los cultos de iglesia.

Hubo una explosión rosariana que se multiplicó por las diversas parroquias, iglesias, conventos, hermandades en un cortísimo lapso de tiempo. Eso obligó a una mínima organización de los devotos y del clero secular y regular. Pronto rebasó la órbita de las parroquias y conventos, erigiendo hermandades los propios vecinos de collaciones y arrabales modestos retablos en los que entronizaron pequeñas imágenes de la Virgen, bien pintada en un lienzo, bien de talla. Esta precaria sede constituía el punto de encuentro para iniciar las estaciones de un Rosario modesto, erigido por los propios vecinos y mantenido con las limosnas de los feligreses.

\subsection{El orden procesional de los cortejos}

En un primer momento salían estas comitivas o «cuadrillas» sin estandarte o Simpecado propio, ni con insignias o imágenes, salvo hachas encendidas o faroles para alumbrar el camino y a los devotos. Iban estos divididos en coros para alternar los padrenuestros y avemarías y estaban dirigidos por uno o dos eclesiásticos que controlaban el orden de la comitiva, marcaban el itinerario y paradas y realizaban los ofrecimientos de los Misterios. Algunos sacaron desde el principio algún estandarte mariano o Simpecado, insignia de gran tradición en Sevilla.

Cada Rosario va organizándose según su idiosincrasia. Hay ya desde muy tempranas fechas un prototipo sevillano que, con influencias del clero regular y secular, especialmente de este último.

He podido localizar en la Biblioteca de la Universidad de Barcelona un interesantísimo impreso «Modo de rezar el Rosario por la calle...» ${ }^{26}$ que, aunque sin fecha, cabe deducir de su tenor que se compone en los primeros momentos de los Rosarios. Se trata de un auténtico directorio para organizar estos primeros cortejos y, aunque está dirigido a los devotos del Rosario del Sagrario tiene una clara vocación universal para todos los de la ciudad.

Debió ser escrito por un clérigo secular de esta parroquia y obedece sin duda a ese afán ya comentado de regular y controlar este incipiente movimiento nacido en gran medida de la propia espontaneidad del pueblo.

Este aserto parece evidente en todas las fuentes consultadas. Hay una iniciativa de la parroquia de San Bartolomé, espontánea, de salir a la calle con motivo

${ }^{26}$ Modo de rezar el Rosario por las calles que deberán observar todos los que acompañan el Rosario del Sagrario de la Santa Iglesia Metropolitana y Patriarcal, y los demás de esta Ilustre y Noble Ciudad de Sevilla (s.a.).

Hispania Sacra, LXII

126, julio-diciembre 2010, 621-659, ISSN: 0018-215-X 
de la muerte de Ulloa con el único objeto de rezar el rosario por las calles. Todo parece indicar que se trataba de algo puntual, una coyuntura emotiva y de fervor en recuerdo y alabanza de un predicador que había dejado tanta huella. Sin embargo se convierte de manera inmediata en todo un acontecimiento paradigmático que se propaga rápidamente por parroquias, conventos e iglesias de la ciudad.

Significativamente no hay una atribución concreta a la iniciativa salvo el influjo del padre Ulloa, lo que otorga un evidente protagonismo de la feligresía con el apoyo y la tutela del clero que pronto percibe la necesidad de organizar los cortejos. Esta es la razón de este impreso.

Lo primero que se detecta en su tenor es que la iniciativa acababa de empezar pues no se menciona en los cortejos ni la cruz ni ninguna insignia. El Rosario lo constituían los propios fieles con la tutela de un eclesiástico y lo que más interesaba era la organización del rezo.

Hasta ahora conocíamos los tenores de diversas Reglas de hermandades rosarianas acerca de la conformación del cortejo, evidenciándose muchos puntos en común entre ellas, incluso frases similares o idénticas.

El impreso establece un concepto del Rosario callejero como una procesión abierta a todo tipo de integrantes, incluso niños acompañados de sus padres, de carácter claramente penitencial, donde los integrantes han de saber guardar en todo momento la seriedad y la compostura, estando muy atentos a la meditación de los Misterios que se consideran y al canto fervoroso de las avemarías a coros y las letanías. Es todo un esquema derivado de las misiones y que pretende ser ejemplificante.

No se establece restricción alguna respecto a las mujeres, lo que parece denotar que la prohibición no ocurrió en un primer momento, sino que fue motivada por diversos abusos que se generalizaron.

Tampoco se refiere a instrumentos musicales que acompañasen a la comitiva, salvo las voces de los fieles, aunque posiblemente se utilizara el bajón en los cortejos ordinarios.

El tenor de las Reglas fundacionales de la Hermandad de la Madre de Dios del Rosario de Santa Ana (1694) ${ }^{27}$ deriva de este impreso al describir el orden del cortejo: un eclesiástico responsable del itinerario, parejas de hermanos con faroles, precediendo cada una a su coro, varios faroles situados de trecho en trecho para alumbrar la procesión y en medio otro eclesiástico encargado de realizar los Ofrecimientos de los Misterios. Finalmente, cerrando el cortejo, marchaban otros dos eclesiásticos para evitar la agregación de otro sexo y cuidar de cualquier contingencia. En el caso de las congregaciones extratemplarias, el

\footnotetext{
27 ArChivo DE LA HeRmandad, Reglas fundacionales. 1694.
} 
propio Hermano Mayor o Mayordomo dirige, con el auxilio del capellán, la procesión.

La estética externa de estos Rosarios se fue consolidando con la inclusión de la que será su insignia más distintiva, el Simpecado, que singularizaba cada comitiva y les permitía considerarse institucionalizados. Este Simpecado, estandarte en forma de M (María) bordado en oro -o con aplicaciones de plata- tiene un lienzo central con una imagen de la Virgen. Se halla relacionado con la «cuestión concepcionista» de 1613. El color más característico de estos Simpecados es el rojo carmesí, aunque los había de color blanco, verde, celeste, morado o negro, según el carácter de la propia institución que lo organiza o si se trata de un Rosario de ánimas o penitencial.

Junto al Simpecado, pronto aparece la cruz, que precede la comitiva y los faroles, de mano y farolas grandes o Marías, con un cierto carácter simbólico, sobre todo las farolas que acompañaban el Simpecado (ser sus portadores estaba lucrado con indulgencias). Igualmente comienza a cuidarse el acompañamiento musical en los coros y se añaden auténticas orquestas. Todo esto hace que la comitiva fuera complicándose con un gran aparato externo, se perdiera la primitiva espontaneidad y se necesitara un continuo desembolso económico para su mantenimiento diario.

En esta conformación de la procesión rosariana van a influir de manera decisiva los religiosos capuchinos, que la promueven sistemáticamente en todas sus misiones. Hay que referirse en especial a Fray Pablo de Cádiz, auténtico «apóstol del Rosario» y al que su hermano de religión Fray Isidoro de Sevilla, que desde 1693 y hasta su muerte colaboró con él en las Misiones, atribuye la institución formal definitiva de los Rosarios públicos, introduciendo al principio una cruz, a la que seguirían los faroles de asta y de mano alumbrando los coros y, sobre todo, un estandarte mariano, que cerraba y presidía la comitiva, saliendo por primera vez la procesión conformada el siete de febrero de 1691 por las calles de Cádiz.28

Fray Pablo estableció en sus Misiones en Cádiz 15 Rosarios en recuerdo de los Misterios, a los que denominó muy significativamente «compañías espirituales». Falleció en olor de santidad el 16 de noviembre de 1694, habiendo dejado un libro «Triunfo glorioso del Santo Rosario», de capital importancia en la historia de la devoción en Andalucía y España. Otorga formal carta de naturaleza teológica y pastoral a los Rosarios públicos y ordena y sistematiza su cortejo con unas muy completas y pragmáticas ordenanzas o constituciones que aprue-

${ }^{28}$ Sobre este religioso, vid. Isidoro DE SEvilla, La nube de Occidente. Vida y virtudes de [...] Fray Pablo de Cádiz, Cádiz, 1702. Fray Pablo llegó a erigir 31 rosarios públicos antes de su fallecimiento en 1694. Fray Isidoro continuó esta labor en Sevilla y otras localidades.

Hispania Sacra, LXII

126, julio-diciembre 2010, 621-659, ISSN: 0018-215-X 
ba el obispo de Cádiz Barcia y Zambrana, ${ }^{29}$ gran promotor de esta devoción desde sus tiempos de sacerdote en Málaga bajo el pontificado de Fray Alonso. Fray Pablo insiste en que la conformación de los Rosarios públicos con estandarte o Simpecado determinado es obra suya y timbre de honor para Cádiz, pero reconoce que el impulso partió del venerable padre Ulloa y de Sevilla.

\subsection{Geografía, rangos y liturgias de los cortejos}

En Sevilla hay una geografía de los Rosarios. Cada comitiva fija su territorio y vecindad, pues de ella depende su supervivencia, ya que los cortejos se sostenían exclusivamente de las limosnas de cofrades y vecinos. A mediados del siglo XVIII estaban contabilizados según la Guía de Forasteros 81 rosarios de hombres y 47 de mujeres, aunque no sabemos si en este número figuran separados los de prima y madrugada que organizaba una misma corporación. Dada la cantidad, eran habituales los conflictos jurisdiccionales o de competencia. Las congregaciones del Rosarios tienden a formalizarse en hermandades diocesanas, con la presentación y aprobación de Reglas por la Autoridad Eclesiástica, pero se aprecia una «formalización popular» que «personaliza» el Rosario y promueve su «reconocimiento» ante los demás Rosarios de la feligresía mediante la adquisición de un Simpecado propio, organizando solemnísimas ceremonias y solicitando el padrinazgo de otra congregación, que apoyaba y reconocía el ingreso de la nueva en la geografía de la collación. Se buscaba así una aceptación «formal» en los Rosarios, independientemente de la licencia clerical si se trataba de congregaciones templarias.

Eran pocos los templos o retablos callejeros que no organizaban un cortejo, con estación en otras iglesias o retablos y el recibimiento festivo de la congregación anfitriona según rituales no escritos, pero que todas respetaban. Había un escalafón o rango entre ellas, primando los rosarios de las parroquias o conventos a los extratemplarios. Se hacían presentes, durante el XVIII en las grandes solemnidades eclesiales. En Sevilla, en ocasión del patronato concepcionista sobre España y las colonias americanas en 1761, salieron a la aurora quince Rosarios de Gala, que realizaron estación a la Catedral, celebrándose allí en capillas distintas 15 misas de alba. ${ }^{30}$

Hasta el último tercio del siglo XVIII la liturgia «sacramental» de los Rosarios responde generalmente al espíritu fundador y se adecua a la religiosidad

\footnotetext{
${ }^{29}$ Barcia es autor de la paradigmática obra «El Despertador Cristiano», colección de diversos sermones dedicados a las fiestas del año, destacando en lo que nos atañe el «Marial» que alcanzó varias ediciones en Cádiz.

${ }^{30}$ Manuel Serrano y OrTEGA, Glorias..., 699-700.
} 
profunda del pueblo. Después las formas van perdiendo sentido: los coros y orquestas se contratan, incluso los propios devotos se «alquilan». Los signos materiales no responden a las inquietudes de un pueblo, con marcada crisis de identidad religiosa, social, pero sobre todo vital. La religión ya no es la única referencia mental y los elementos sagrados van poco a poco abandonando la vía pública y retornando a los templos. El Rosario público cotidiano empieza a ser una reliquia del pasado. La imagen de la Virgen, recobra su protagonismo en la Procesión anual en su advocación.

Los organizadores quieren crear una identificación de su Rosario sobre todo con la insignia del Simpecado. Al principio la efigie de la Virgen, era casi siempre la Inmaculada. Ahora se encarga con la imagen de su titular, del Rosario o con otra advocación

\subsection{Una clasificación de los Rosarios}

Puede establecerse una la tipología de estos Rosarios, según la entidad organizadora y su sede canónica.

a) El primer grupo es el de los Rosarios parroquiales. Surgieron ya en 1690 y se encontraban plenamente constituidos en el primer tercio del siglo XVIII. Eran un revulsivo para la vida de la parroquia, dinamizaron su pastoral y crearon una actividad cotidiana y permanente. El clero los controlaba y dirigía, les daba sus estatutos estos Rosarios y fijaba las estaciones por las calles.

b) Los rosarios conventuales están bajo la dirección y amparo de la Orden religiosa titular. Muy parecido a los parroquiales, intensifican su carácter misional. Fueron significativos los de los dominicos, capuchinos, carmelitas, franciscanos y otras órdenes de vida activa. A ellos hay que sumar los establecidos en iglesias de la Compañía de Jesús.

Los Dominicos promueven procesiones diarias del Rosario o varios religiosos acuden a algunas de la feligresía de sus conventos o incluso de hermandades parroquiales como la de San Marcos en Sevilla. A raíz de las Misiones de Fray Pedro Vázquez Tinoco (1735), ${ }^{31}$ la Orden reestructura y reactiva los Rosarios públicos, que estaban ya en cierta crisis. Crea los cortejos de mujeres, que fueron un éxito extraordinario, y los de niños y jóvenes. En Córdoba y su provincia destaca la figura de Fray Francisco de Posadas. Desde entonces las propias Cofradías adoptan en sus constituciones el uso callejero. En San Pablo,

\footnotetext{
${ }^{31}$ Sobre este dominico, vid. mi breve artículo «Los rosarios femeninos » en la revista Humeros, boletín de la Hermandad del Rosario, $n^{\circ}$ 54, febrero 2004, pp. 8-9.

Hispania Sacra, LXII

126, julio-diciembre 2010, 621-659, ISSN: 0018-215-X
} 
se observa la creación de congregaciones rosarianas dedicadas al uso público, bajo la dirección de un capellán de la Orden, pero dotadas de mayor autonomía que las otras Cofradías que buscan una integración efectiva en los rosarios de la ciudad. Hay problemas entre las feligresías de cada convento y aquellas de las parroquias vecinas, y litigios entre el clero regular y secular.

c) Los Rosarios de hermandades y cofradías los organizan los propios cofrades de una hermandad diocesana o también las cofradías dominicas. Tenían amplia autonomía respecto al clero. El Rosario público pasa a formar parte de su instituto y cuidan el culto a la imagen titular.

La Hermandad de Nuestra Señora de Europa, establecida en una humilde capilla-retablo en las Pasaderas de San Martín en Sevilla, ${ }^{32}$ o la de Nuestra Señora del Socorro en Córdoba. Otras surgen al amparo de este uso callejero como la de la Aurora María y Dolores del Puente en Málaga y, poco a poco, se va creando una devoción concreta a la imagen de la Virgen, a la que da un título determinado, primordialmente el de Rosario. En el caso de las primeras, la organización del Rosario se encomendaba a una diputación especial, que gozaba de gran autonomía jurídica y económica. Era muy común este uso con los Rosarios de mujeres.

Dentro de las hermandades, cabría distinguir entre las penitenciales, sacramentales, o las de Gloria, mucho más numerosas, pues lo usual era que todas ellas promovieran entre sus actividades la salida del Rosario público.

Respecto a las cofradías, al principio parecieron reacias a incluir el uso en su instituto, pero estaba ya extendido y por mor de la competencia devocional, ya lo asumieron en las primeras décadas del siglo XVIII, como ya se ha apuntado.

d) Rosarios espontáneos o/ y de retablos callejeros: fueron los primeros que salieron, pues en ellos apenas había una organización definida. Poco a poco esta denominación de espontáneo se fue circunscribiendo a aquellos organizados por grupos de vecinos de una colación o arrabal en un ámbito separado del templo, normalmente en torno a un retablo adquirido a sus expensas en plena vía pública y en el que colocaban una imagen de la Virgen, bien en un lienzo, bien de talla y que constituía el punto de reunión para comenzar el Rosario. Cuando se consolidaba el uso, se constituían en congregación y, posteriormente, en hermandad. Lo usual era ampliar el retablo, para guardar en él las insignias del Rosario o alquilar o adquirir un local contiguo. Muchas hermandades rosarianas nacieron así y conservaron como sede canónica este retablo. Eran Rosarios por lo general muy humildes, que apenas se sostenían de las pocas limosnas del

\footnotetext{
32 Vid. mi monografía La Muy Ilustre Hermandad de Nuestra Señora de Europa..., Sevilla, Consejo de Cofradías, 1983.
} 
vecindario, pero que crearon en su entorno un sentido muy auténtico de religión vital y marcaron un primer asociacionismo socio-económico. Reactivaron la vida del barrio y fueron artífices de la conformación rosariana en su dimensión más popular, pues aquí la autonomía frente al clero era casi absoluta hasta que se constituían en hermandades.

e) Rosarios de comunidades monásticas o conventuales: merced al testimonio del citado Vázquez Tinoco, ${ }^{33}$ se conoce que en el siglo XVIII varias comunidades monásticas femeninas y diversos conventos de frailes regulares organizaban en Sevilla cortejos del Rosario público, sobre todo de madrugada. Se conocen incluso coplas como las del monasterio de dominicas de Santa María la Real: Si quieres verte libre / del Adversario,/ ten devoción y afecto/ con el Rosario./ Que sus Misterios/ son armas, y defensal contra el infierno (Ave María) /cuyo nombre a las almas/ causa alegría. (Marcos García Merchante.1764). ${ }^{34}$

f) Rosarios de órdenes terceras dominicas: en los cenobios dominicos, los terciarios sacaban su procesión del Rosario por las calles. Conocemos el de San Pablo de Sevilla, a la hora de la aurora, el de San Pablo de Córdoba y el de Santo Domingo, en Écija.

Las procesiones salían a diario de sus sedes, al toque de Oraciones Prima Noche. Poco a poco se van generalizando las estaciones de Madrugada. Era muy normal que de una misma iglesia salieran ambas el mismo día, y no pocas veces, organizadas por entidades distintas. El Rosario de Prima era la procesión más genuina en el siglo XVIII.

Según Martín Braones, en los festivos las parroquias solían organizarlo también por las tardes. Era procesión especial, que reunía a muchos feligreses y con estaciones en algunas iglesias, conventos, o la Catedral. Había ceremonias festivas de recibimientos. Serán pronto tradicionales y crearán unos ritos que expresan muy bien las relaciones entre los Rosarios.

Este rosario vespertino «supernumerario» del convento de San Pablo era parroquial y familiar. En los años 90 ya salían mujeres en estos cortejos desde el convento de San Pablo en Córdoba. ${ }^{35}$ Se celebraban en una hora prudente y recatada sin peligro de «irreverencia».

\footnotetext{
${ }^{33}$ Ave María. Copia de una carta que de Sevilla a Barcelona al Coronel Don Antonio García Paredes... escribió el P. Presentado Fr Pedro Vázquez Tinoco, impreso sin fecha.

34 Marcos García Merchante, Manual de noticias concernientes a la iglesia del señor San Vicente de Sevilla, Sevilla, 1763., fol 273. El impreso está anexo al manuscrito y se titula «Espirituales coplas que un devoto del Santísimo Rosario componía para meditar sus sacratísimos misterios»

${ }^{35}$ Cfr. Pedro de Alcalá, O.P., Vida del V. Siervo de Dios el P. Presentado Fray Francisco de Posadas..., Madrid, J. Zúñiga, 1737., p. 120.
}

Hispania Sacra, LXII

126, julio-diciembre 2010, 621-659, ISSN: 0018-215-X 
El 7 de diciembre de 1690 la congregación del Rosario de Nuestra Señora de la Antigua, de las Gradas de la Catedral sevillana salió procesión del Rosario al toque de alba. ${ }^{36}$ El Rosario de madrugada fue consolidándose. En siglo XVIII la mayoría de las congregaciones y hermandades solían organizar a diario ambas procesiones, o, al menos, tenían instituida la de madrugada para los días festivos.

Este Rosario, a diferencia del de Prima y el de tarde, cuando la procesión se recogía en su sede, los cofrades asistían a la misa denominada «de alba». Es un signo de estabilidad en el número y concurso de devotos y cofrades y de ingresos económicos para sufragar los gastos procesionales y el estipendio del capellán de misas. Favorece la comunión con la religiosidad oficial gracias la participación de los cofrades en la eucaristía. Estas misas de alba facilitaban el cumplimiento del precepto de la Iglesia a los trabajadores del campo que comenzaban muy pronto su jornada laboral, y a los pobres y marginados, que a veces no se atrevían por su indumentaria a participar en los cultos de iglesia.

El Rosario de madrugada se convertirá en la segunda mitad del siglo XIX de manera generalizada en la procesión por antonomasia. Cuando en su segunda mitad decrecen hasta desaparecer las salidas a diario, se mantendrá en los días festivos, solemnidades y será esencial en la predicación de las Misiones.

La denominación «Rosario de la aurora» comienza ser popular en la segunda mitad del siglo XVIII y, sobre todo, en el XIX. Fue habitual en los en los ambientes rurales. Aparecen desde finales del XVII congregaciones y hermandades con el título de Nuestra Señora de la Aurora con sede en capillas o ermitas, a modo de contrapunto más espontáneo y popular a la cofradía dominica de la parroquia, con cuyo clero solían existir no pocas tensiones y conflictos jurisdiccionales.

A fines del XIX y comienzos del XX comenzaron los denominados «Rosarios de Faroles» en varias localidades españolas (Zaragoza, Vitoria, Haro, Sigüienza). En Andalucía fue muy importante el de Antequera (Málaga), del que se conservan algunos faroles monumentales.

En la actualidad el Rosario público suele salir a primeras horas de la mañana acompañado por lo general de la imagen de la Virgen titular de la corporación. En la provincia de Cádiz se celebran también por las noches los denominados «Rosarios de antorchas».

Por su periodicidad, los rosarios públicos eran ordinarios y extraordinarios. Los primeros se organizaban a diario, a prima noche y en los días festivos, por

\footnotetext{
36 Todavía se conserva esta fecha en una inscripción mural en lo que fue su capilla-retablo, hoy entrada a la Institución Colombina.
} 
la tarde y de madrugada. Los extraordinarios salían en algunas ocasiones a lo largo del año. Todo rosario poseía por lo general un doble juego de insignias, uno más simple: cruz de palo, faroles de baja calidad... simpecados con bordados simples y lienzos con imágenes de tosca factura y otro de mayor riqueza con auténticas obras de arte en orfebrería y bordados, destacando sobre todo los Simpecados, que podían ser de color rojo-carmesí (los más frecuentes), blancos o celestes.

Los Rosarios extraordinarios podían ser de gala, de Ánimas, penitenciales, de rogativas y de acción de gracias. Los de gala eran los más importantes. Eran los celebrados en fiesta principal de la institución que lo organizaba y en alguna efeméride especial. En ellos se lucían las mejores insignias: cruz dorada, farolas artísticas (Marías) y el Simpecado de Gala. En varias hermandades se organizaba con este Rosario las «Novenas de calle» como sucedía con el de la Hermandad sevillana del Rosario de Santa Catalina. Consistían en la salida procesional por las calles de la feligresía durante los nueve días en que se celebraba la Novena de iglesia. Solía llevar el cortejo acompañamiento musical de violines y bajones junto a cantores especializados: tenor, tiples y vicetiples, y un coro infantil que entonaba las avemarías.

Muy pujantes durante el siglo XVIII y primera mitad del XIX, su declinar coincide con la crisis de los Rosarios de Prima y el progresivo auge de la Procesión anual de la imagen titular, que viene a sustituir al Rosario de Gala con todas sus insignias, incluida el Simpecado, pero ya como elemento secundario de lo que ya es centro devocional: la imagen titular.

Los de Ánimas fueron muy importantes en el siglo XVIII. Salían en los primeros días del mes de noviembre (Novena de Ánimas) haciendo estación a cruces, cementerios o retablos de ánimas. Tenían Simpecado propio de color morado o negro. Fue pionera la Hermandad del Rosario de la Asunción de las Gradas de la Catedral de Sevilla, dependiente de la Sacramental del Sagrario. La primera comitiva salió el 2 de noviembre de 1712 en prima hora y de madrugada. Matute se refiere a Francisco José de Aldana y Tirado como principal promotor de esta iniciativa. ${ }^{37}$ Se publicó un folleto invitando a todos los Rosarios de España a sumarse a esta práctica, de gran predicamento en la ciudad y posteriormente en toda la provincia. ${ }^{38}$

En noviembre los cementerios de las parroquias eran estación obligada de estos rosarios. Se cantaba responsos y coplas sobre el tema de la muerte. Desta-

\footnotetext{
37 Justino Matute y Gaviria, Anales... año 1712 (10), Sevilla, 1887.

${ }_{38}$ Novenario perpetuo y general con que el Rosario de el Sagrario de la Santa Iglesia Patriarcal de Sevilla combida a todos los Rosarios de España a que desde el día de los difuntos de cada un año ofrezcan [...] todos los Rosarios de dentro y fuera de las iglesias por las Benditas Ánimas del Purgatorio, Sevilla, 1712.

Hispania Sacra, LXII

126, julio-diciembre 2010, 621-659, ISSN: 0018-215-X
} 
can las estaciones en el de San Sebastián, en el hospital del Amor de Dios o en el alto de los Humeros, todos en Sevilla. Estaban allí enterrados miles de sevillanos fallecidos durante la peste en 1649 y en 1800. Las ceremonias eran auténticas «fiestas de la muerte».

Muy importantes durante el siglo XVIII, los Rosarios de ánimas comienzan a declinar en la segunda mitad del XIX en su expresión callejera. Se reunían en el interior de las iglesias donde se seguían cantando las coplas.

Los penitenciales salían en Cuaresma y hacían estación en el humilladero de la Cruz del Campo en Sevilla. Salían todos días de la Semana Santa, especialmente el Viernes Santo. En la Regla de la Cofradía de La Lantejuela (Sevilla) en 1797 se ordena que todos los Viernes Santos «se aga un Rosario, al cual asistan todos los hermanos con las penitencias que sus fuerzas alcancen (consultando cada uno primero con su confesor las penitencias que podía hacer) y después de entrar en la iglesia y visitar al Sagrario se rezará el Rosario leyendo al final de cada diez un paso de la Pasión» Se ha documentado en ellos los Simpecados negros.

Los de rogativas hacían estación cuando la ciudad sufría alguna calamidad pública, como sucedió en 1800. Los de acción de gracias, en cambio, se celebraban con motivo de acontecimientos felices como la visita del rey Felipe V a Sevilla.

Los rosarios públicos, al menos los de prima noche y los de madrugada, admitían en sus comitivas exclusivamente a hombres. Estaba taxativamente prohibido por la autoridad eclesiástica, pero la insistencia en la norma hace sospechar que asistieran mujeres.

El dominico Pedro Vázquez Tinoco promovió Rosarios exclusivos de mujeres. Comenzaron en 1730 en su tierra extremeña y, en 1735, en la ciudad de Sevilla, con motivo de una Misión. La primera procesión fue la de la parroquia de Santa Cruz. El secretario de la Hermandad de la Virgen de la Paz de esta iglesia, cuyo instituto fundamental es el Rosario público, lo narra así y explica cómo esta corporación colaboró en la organización y algunos problemas que hubo:

[...] pidió (Tinoco)se formara y saliera desta dicha iglesia un Rosario de señoras mugeres las tardes de los días festivos de todo el año, lo que entendido por diferentes hermanos que se hallaron presentes, dispusieron que se executase conforme lo encargó el Padre, como así se hizo, empezando desde dicho día (1 de Noviembre) la reforma: llevaron el Simpecado y faroles altos y vajos diferentes señoras. Iba en medio del Rosario un coro de niñas entonando el Avemaría. Finalmente fueron quatro caballeros eclesiásticos y hermanos desta Hermandad gobernando el Rosario, poniéndolas en orden y estorbando el que los hombres se asercasen y les dixessen algo [...].39

39 Archivo Hermandad de Santa Cruz, Libro de actas de la Hermandad de la Paz, certificación de 3 de noviembre de 1736 , fols 123 vto- 124 . 
Fue todo un acontecimiento y suscitó bastantes críticas, pero adquirió notable expansión, como entidad autónoma o como sección dependiente de Rosarios masculinos o de una congregación. En la parroquia de Santa Catalina de Sevilla hubo una congregación con Simpecado e insignias propias al igual que en la Hermandad de los Negritos. Otras gozaban de pleno reconocimiento de hermandad como la del Rosario cantado de Nuestra Señora del Carmen de Pedrera (Sevilla), fundada en $1751 .{ }^{40}$ En 1740 existían más de treinta y seis en la ciudad y la Reina, se declaró el 4 de octubre Hermana Mayor de todos los Rosarios. Eso fue acallando las críticas.

En Tarifa (Cádiz) que parece remontar la instauración de estos Rosarios a 1718 , pero habría que revisar si se refería a cortejos callejeros. ${ }^{41}$

En la Hermandad del Socorro de Córdoba se documenta en 1740 un Rosario femenino como congregación autónoma. En La Rambla forman la hermandad del Rosario de Nuestra Señora de los Ángeles en 1746.42

Estos Rosarios son el primer dato del protagonismo de la mujer en la conformación de la religiosidad popular sevillana y fueron además decisivos para revitalizar el uso devocional de los Rosarios públicos.

En la provincia de Sevilla fueron muy importantes en Cantillana durante el siglo XIX y parte del XX. Existía ya rivalidad entre los de la Hermandad de la Divina Pastora y los de la Asunción.

La mayoría de los Rosarios estaban ya constituidos en congregaciones a finales del siglo XVII, sin estatutos formalmente aprobados por la Autoridad Eclesiástica, o en hermandades. La hermandad se convierte en la institución que preserva y canoniza una devoción surgida espontáneamente en el pueblo. Es una asociación peculiar y de honda tradición, que servirá como medio de integrar en la Iglesia una religiosidad, no coartando o limitando su espontaneidad, sino dotándola de estructura de gobierno y con una dimensión cultual y caritativa, dentro de una institución aprobada por la jerarquía, pero con autonomía y que el pueblo siente como suya, pues es marca el pulso de su vida.

Eso da a la religiosidad popular una dimensión de comunión eclesial, pero nunca faltaron disensiones entre cofrades y clero. Estas, muy claras en el inicio, fueron cada vez menores hasta que desapareció todo tipo de jurisdicción exclusiva de los dominicos. Las Cofradías del Rosario coexistieron con las nuevas

\footnotetext{
40 Se conserva en el archivo parroquial un libro de actas y cuentas que da comienzo en 1751 y culmina en 1840 .

${ }^{41}$ Cfr Juan Antonio Patrón Sandoval, «Los Rosarios públicos en Tarifa (2)», en Aljaranda. Revista de Estudios Tarifeños, $\mathrm{n}^{\circ}$ 59, diciembre 2005, pp. 20-30.

42 José MonTáÑEZ LAMA, Historia de La Rambla y apuntes históricos y geográficos de las poblaciones de su partido, Córdoba, 1912 (reedición de 1985), p. 114.
}

Hispania Sacra, LXII

126, julio-diciembre 2010, 621-659, ISSN: 0018-215-X 
hermandades diocesanas, dependientes de la Mitra y sin más vinculación con las cofradías que la participación en sus gracias e indulgencias concedidas a aquellas por los Papas, previa solicitud e inscripción de los cofrades de cada hermandad en los libros de la Primitiva Cofradía del Rosario del convento de San Pablo, trámite que debía verificarse anualmente. Fueron muchas las hermandades y congregaciones que lo hicieron.

\section{LAS HERMANDADES y COFRADÍAS DEL RoSARio}

\subsection{Las cofradías dominicas}

$\mathrm{Al}$ referirnos a las hermandades rosarianas, hay que establecer la siguiente división: Cofradías del Santo Rosario y Hermandades Diocesanas

La Cofradía del Rosario, nacida a fines del siglo XV a iniciativa de Fray Alano de la Roca, formaliza definitivamente el rosario, de honda tradición monástica, y lo trasvasa al ámbito urbano, creando un asociacionismo seglar en torno a los conventos de la Orden Dominicana. Parece que hubo una iniciativa dominica autónoma en la península con Fray Juan Agustín, carismático misionero rosariano, muerto en olor de santidad en San Pablo de Córdoba en 1476.43

La Cofradía adquiere mayor arraigo entre la población en la segunda mitad del XVI, siendo un hito trascendente la victoria naval de Lepanto (1571). Tras ella, el instituto de las cofradías establece las denominadas fiestas mensales (mensuales) con misa solemne y procesión claustral los primeros domingos, y obligación de confesar y comulgar, siendo la principal la de octubre, también denominada de la «Batalla Naval» conmemorativa de Lepanto y dedicada especialmente a la Virgen del Rosario, con función, panegírico, música y procesión pública por la feligresía con la imagen. Se celebraron en la festividad de la Purificación.

Bastante relieve tenía en el primer domingo de mayo «La Fiesta de las Rosas». En la Regla de la Cofradía de Alcolea del Río (Sevilla) (1724) se preparaba la celebración en un cabildo previo, estableciéndose que los diputados llevaran canastas de flores para hacer ramos, que portarán los hermanos de cirio (150) en la procesión. ${ }^{44}$

${ }^{43}$ Sobre este misionero dominico, natural de Lérida, vid., Francisco Diago, OP, Historia de la provincia de Aragón de la Orden de Predicadores desde su origen hasta el año 1600, Barcelona,1599, fols 73-74 vto y 220 vto.

${ }^{44}$ ArChivo HistóRICo NaCional, Consejos Suprimidos, legajo 1744, nº 24. 1797. 
El segundo gran instituto es el fomento de la oración mental y vocal del Rosario, de manera individual (al menos una vez a la semana) y colectiva, rezándolo a coro en la iglesia con sus meditaciones. El Rosario era mucho más que una oración Era un signo sensible, casi un sacramento en que se contenían no ya los Misterios de Salvación, sino la propia salvación eterna de los cofrades. Por eso, en las reglas se establece la obligación de llevar el rosario en las fiestas mensales y en los entierros de los hermanos.

Muy importante era el sufragio por los cofrades difuntos y acompañamiento en su entierro. A este instituto asistencial se dedica apartados significativos en las reglas, muy minuciosos, sobre el aparato mortuorio, acompañados, misas de sufragio y, en su caso, la estación del Rosario al domicilio... La Cofradía del Rosario estaba muy vinculada a la devoción a las ánimas del purgatorio. Había listas de difuntos inscritos por sus familiares, lo que otorga a la corporación un cierto sentido de «comunión de los santos». En el cuadro de ánimas que figura junto al altar de la Cofradía de Huévar (Sevilla), la Virgen del Rosario intercede a Dios por las benditas ánimas. Es impresionante el cuadro de la Cofradía de Montilla (Córdoba) que presidía el panteón de cofrades y hoy se halla en la sacristía parroquial. En Villamanrique la Inmaculada reparte rosarios a las ánimas. Había cofradías con el título «del Rosario y Ánimas», como sucedía en Camas, ${ }^{45}$ Castilleja de la Cuesta, Constantina, ${ }^{46}$ Lebrija y Villaverde del Río. ${ }^{47}$ En Sevilla o en Dílar (Granada), ésta fundada en 1722, los cofrades sacan el Rosario por la calle en sufragio por sus difuntos. 48

La inscripción como cofrades, desde los primeros tiempos de su institución, es abierta y gratuita tanto para hombres como para mujeres. Esta era una de las bases de la Cofradía desde su fundación en 1475 (Colonia). No obstante, ya en las reglas de las primeras se establecía una limosna o cuota anual amparándose en los gastos de cera para las fiestas. Se observa, pues, una dualidad entre la norma general, y la práctica concreta de las corporaciones. En el siglo XVIII aparecen claramente la distinción entre cofrades de número, primeros o «del cirio» en número simbólico relacionado con el Rosario $(15,50,150 \ldots)$ y los de-

\footnotetext{
${ }^{45}$ En el archivo parroquial se conserva un inventario de 1725 de la Hermandad de las Ánimas Benditas y Nuestra Señora del Rosario. Existía antes la Cofradía de Ánimas que, al encontrarse muy decaída a comienzos de siglo, decidiría adoptar el instituto rosariano, merced a la gran devoción existente y que corrobora una visita pastoral de 1698. Cfr. Juan José AnTEQuera Luengo, Noticias y documentos para la historia de Camas, Camas, 1981, pp. 118-119.

46 Así se atestigua en muy diversa documentación desde el siglo XVIII, según las investigaciones de José Luis Ortiz Gómez. Se la conocía popularmente por la de Ánimas.

${ }^{47}$ Gracias a las investigaciones de Manuel Morales Morales conocemos que existía ya en 1615 una Cofradía del Rosario y Ánimas del Purgatorio. Cfr. Archivo Parroquial de Villaverde. Libro 98. Cuentas de la Hermandad de Ánimas (1619-1691)

48 Miguel LóPeZ-Guadalupe MuÑoz, 385.
}

Hispania Sacra, LXII

126, julio-diciembre 2010, 621-659, ISSN: 0018-215-X 
nominados «de gracias», es decir, el resto de los cofrades cuya entrada es libre y gratuita para ganar las gracias y privilegios espirituales concedidos a estas corporaciones.

Esta cuestión es promovida por la propia Orden de Predicadores. Así se expresa el padre promotor que erige la Cofradía de Benacazón en 1747: «[...] advirtiéndoles que unos eran cofrades solamente para ganar el incomprehensible tesoro de indulgencias y que estos debían ser admitidos de cualquier calidad o condición que fueran, aunque fuesen de los de más bajo linaje, y otros eran cofrades numerarios para los subsidios temporales, y éstos habian de contribuir con un ochavo cada semana y que había de ser obligación de la Hermandad asistir a estos cofrades en su entierro con luces en las manos rezando el Stmo. Rosario y con paño para el féretro... ${ }^{49}$

Sólo a los numerarios corresponde el gobierno y la administración de la Cofradía. Se les denominaba «de cirio» o «lumbre» pues eran los encargados de llevar los cirios o luminarias en las procesiones mensales y en las velas y entierros de los cofrades difuntos. Estos cofrades numerarios en ocasiones también se subdividían en los «hermanos del cirio» y «los esclavos». Así se observa en la Regla de la Cofradía de Puebla de Cazalla (Sevilla) donde los numerarios eran 33: los primeros (18) eran una especie de «hermanos protectores» que pagaban una limosna de entrada, cuota anual y tenían derecho a portar un cirio en las funciones, mientras que los «esclavos» (15) estaban encargados del Rosario público, las demandas y también de muñir a los cofrades. Incluso se menciona una tercera categoría de cofrades, equiparados a los numerarios, que son los «honorarios». ${ }^{0}$ En Cabra (Córdoba) la Cofradía contaba con 199 cofrades de número divididos en 17 cuadrillas, cada una de las cuales tenía la responsabilidad de una fiesta mensal o en honor a la Virgen (portar el estandarte, las andas...)..$^{51}$

El Rosario adquiere un avance espectacular, y con él, las Cofradías, a partir de la segunda mitad del siglo XVII. En Sevilla era obispo el dominico Fray Pedro de Tapia, que favoreció su fundación en las parroquias. Los frailes dominicos, con especial licencia del Provincial y del prior de los conventos, especialmente San Pablo, acudían a los pueblos a solicitud del clero parroquial y de los vecinos para erigir las Cofradías en nombre del Maestro General de la Orden. Había en cada provincia padres promotores especialmente dedicados a ello. La llegada del promotor al pueblo se convertía en una gran fiesta del Rosario, con

\footnotetext{
49 Documento inserto en el libro de Reglas de 1732; cfr. Benacazón. Archivo de la Hermandad del Rosario.

50 Archivo Histórico Nacional, Consejos Suprimidos, legajo 1653, nº 21. Expediente de aprobación de Reglas. 1791.

51 Archivo Parroquial de Santo Domingo de Cabra, Reglas de 1598, capítulos 1 y 3.
} 
una liturgia solemnísima y emotiva. El auditorio vibraba con las palabras del dominico, que erigía formalmente en la parroquia mayor la Cofradía, leía sus estatutos, bendecía rosarios y recibía a los primeros cofrades ${ }^{52}$ Este fenómeno se repite en todas las diócesis andaluzas a iniciativa de sus prelados.

Desde 1604, los Papas ordenaron que tuvieran aprobación diocesana. Quedaban sujetas a la jurisdicción episcopal, aunque la Orden de Predicadores gozaba del privilegio de erigir la Cofradía, nombrar al capellán y conceder las gracias e indulgencias concedidas al rosario. La primera gran etapa de fundación de cofradías fue en la segunda mitad del XVI y así se observa en distintas poblaciones, pero las misiones predicadas por los jesuitas en Sevilla en el siglo XVII y las de los capuchinos en el XVIII fomentaron el Rosario y la fundación de congregaciones y hermandades diocesanas de Nuestra Señora del Rosario.

Esta jurisdicción episcopal fue imponiéndose, como se establece en los sínodos para las demás asociaciones y congregaciones religiosas seglares. Con todo, en la segunda mitad del XVII lo es en Sevilla efectiva y ya en el XVIII, con la universalización rosariana tras el fenómeno de los cortejos públicos (1690), la Orden de Predicadores quedó, en la práctica, con una tutela meramente espiritual mediante la agregación de los cofrades de las nuevas hermandades estrictamente diocesanas de Nuestra Señora del Rosario a la Cofradía matriz de San Pablo. ${ }^{53}$

Los dominicos y sus cofradías no se resignaron a perder el monopolio. Interesaron de los papas en la primera mitad del XVIII que mantuviera efectivo la exclusividad de la Orden en la fundación de hermandades y cofradías como condición para gozar de sus gracias e indulgencias. En los años 20 y 30 hubo una campaña misional en la provincia de Sevilla destinada a fundar nuevas cofradías o restaurar otras, caídas en decadencia o convertidas en corporaciones diocesanas. Así fue en el Aljarafe con las de Benacazón (1732, renovada en 1747), Gelves (1656, restaurada en 1731), Gines (1675, restaurada en 1725) o Umbrete (1643, renovada en 1725). Lo mismo pasó en la Sierra de Aracena (Huelva) donde hubo tres momentos fundacionales: finales del XVI (Zufre, 1576), la segunda mitad del XVII y los años centrales del XVIII..$^{54}$

Aunque parecía el Rosario público, fenómeno en principio espontáneo, aunque formalizado ya entre 1690 y 1691, no tenía cabida en las Cofradías domini-

\footnotetext{
52 Cfr. Mi artículo, «La nueva fundación de la Cofradía del Rosario de Umbrete en 1725: un acontecimiento pastoral y reivindicativo de la Orden de Predicadores en la diócesis de Sevilla», en ASCIL, Anuario de Estudios Locales, ${ }^{\circ}$ 1, 2007, en prensa.

${ }^{53}$ Sobre el fenómeno de los Rosarios públicos, vid. mi monografía ya citada El Rosario en Sevilla...

${ }^{54} \mathrm{Mi}$ artículo citado «Religiosidad popular y tradición en la Sierra de Aracena»...

Hispania Sacra, LXII

126, julio-diciembre 2010, 621-659, ISSN: 0018-215-X
} 
cas, hemos localizado que ya en 1718 hay Cofradías que sacan su Rosario por las calles como ocurre en Écija y en 1747. La Orden de Predicadores, al instituir las cofradías, contempla el Rosario público como una actividad más, junto con las fiestas mensales. En Montoro (Córdoba) hay un acuerdo capitular sobre este punto en $1725^{55}$ y en Arjonilla (Jaén) en 1731 a la Aurora. ${ }^{56}$

Sólo podía fundarse una cofradía en cada ciudad o pueblo. La ciudad de Sevilla fue una excepción, pues las hubo cada cenobio dominico: San Pablo, Regina, Porta Coeli, Monte Sión, Santo Tomás y San Jacinto. En la provincia sí se respetó esta norma: Carmona, Écija, Marchena, Osuna... y en las parroquias de los pueblos que no tenían conventos de la Orden.

Se fundaron con licencia expresa del Maestro General dominico cofradías en el monasterio de la Cartuja de Santa María de las Cuevas ${ }^{57}$ y en la clausura del monasterio cisterciense de San Clemente en la capital, ${ }^{58}$ o el de San Isidoro del Campo en Santiponce. ${ }^{59}$

En Córdoba, en la segunda mitad del XVI proliferan cofradías en toda la diócesis por iniciativa del prelado dominico Fray Martín de Córdoua y Mendoza, que concede en 1580 a Fray Diego Núñez del Rosario, dominico, licencia especial para que funde en cada población.- Se erigieron cofradías también en cenobios de clausura como documenta el profesor Aranda Doncel en el caso de la comunidad jerónima femenina de Santa Marta, muy cercana a San Pablo. ${ }^{60}$

La devoción del Rosario comienza en Granada con la reconquista de la ciudad por los Reyes Católicos. Se funda una Cofradía a fines del siglo XV en la iglesia del convento dominicano, en la que es tradición ingresaron como hermanos los propios reyes y el Arzobispo Fray Hernando de Talavera. En Málaga, en el primer cenobio dominico en el barrio del Perchel ya en 1495, no tardó en fundarse a Cofradía ${ }^{61}$ En la ciudad de Almería capital se funda el convento

\footnotetext{
55 Juan ARANDA Doncel, «Las hermandades y los Rosarios públicos..., p. 372.

56 Ildefonso RUEDA JÁNDULA, «Aproximación histórica al origen de la patrona de Arjonilla. La crisis de un sistema dual entre asociaciones del Santo Rosario», en Salvador RodríGuez BECERRA (Coord.), Religión y Cultura, Sevilla, 1999, volumen 1, p. 409.

57 Cfr Baltasar Cuartero y Huerta, Historia de la Cartuja de Santa María de las Cuevas..., Madrid, 1950 , tomo 1 (p. 447) y tomo 2 (pp. 27, 183 y 300)

${ }_{58}$ Muy recientemente he podido acceder al archivo monástico donde se halla un Libro de la Cofradía del Rosario. Se funda la Cofradía en 1653 mediante licencia del Prior del Convento de San Pablo y se renueva en 1701. Las últimas partidas son de 1779. Sus cofradas eran las propias religiosas y la servidumbre del monasterio.

59 Amparo Rodríguez Babío, «Muy Antigua, Real, Ilustre y Fervorosa Hermandad del Santísimo Sacramento y Cofradía de Nuestro Padre Jesús Nazareno, Nuestra Señora del Rosario y Divina Pastora», en Nazarenos de Sevilla, Sevilla, Tartessos, 1997, t. III, pp. 268-273.

${ }^{60} \mathrm{Cfr}$. «Las hermandades y los rosarios públicos en la diócesis de Córdoba durante la Edad Moderna», en H. Paz Castaño y C. Romero Mensaque, 363-376.

${ }^{61}$ Rafael Retana Rojano, 391.
} 
de Santo Domingo en 1492. Desde él se extiende la devoción a toda la provincia. En la provincia Jaén se documenta su existencia a fines del XVI, en la ciudad y Cambil (1599), Noalejo (1583) y Mancha Real (1590).

\subsection{Las hermandades diocesanas}

La iniciativa la fundación de hermandades fue principalmente de los laicos. Las Misiones jesuíticas sevillanas con las hermandades de Jesús Crucificado y Nuestra Señora del Rosario y los Rosarios públicos fueron decisivos para la creación de las hermandades diocesanas. Fueron más en las capitales y ciudades que en las poblaciones rurales donde la Cofradía del Rosario es la principal y casi única referencia junto con las congregaciones y hermandades del Rosario de la Aurora.

Durante la gran expansión de los siglos XVII-XVIII, hay documentadas la ciudad de Sevilla aproximadamente 80 hermandades diocesanas, sin contar con las congregaciones de algunos templos. En Córdoba, Aranda Doncel cuantifica 18 y en Málaga, Retana ha contabilizado 14. Espinosa de los Monteros se refiere a las congregaciones o hermandades en Cádiz a partir de los rosarios públicos y llega a documentar unas 32 . En el resto de las provincias faltan datos suficientes y estos confunden en muchos casos las cofradías dominicas y las hermandades diocesanas.

En el siglo XVIII es usual que los hermanos de las diocesanas soliciten la agregación a la Cofradía de la localidad a fin de lucrarse de las gracias concedidas en exclusiva a ésta e incluso se solicita la colación dominica, es decir, la erección de la hermandad como Cofradía en las poblaciones donde no existe o ha desaparecido. En su instituto se conjugan la salida del Rosario público a prima noche y/o madrugada, el culto y veneración a la imagen titular y los sufragios por los cofrades difuntos.

Desde siglo XIX predominan estas hermandades mientras decaen las cofradías, que se acomodan al modelo institucional de las diocesanas. Va desapareciendo el Rosario público y dan paso a la procesión anual de la imagen y los cultos. Son muchas las hermandades que permanecen, pero en la provincia de Almería parece que sólo continua activa la de Roquetas de Mar, cuya imagen es Patrona de la población y data de 1784.

Se documentan estos tipos: Hermandades de Nuestra Señora del Rosario con ejercicio público callejero, Hermandades rosarianas con otra advocación y dedicadas al ejercicio público callejero, Congregaciones rosarianas o de Nuestra Señora del Rosario dedicadas al ejercicio público callejero, Hermandades de Nuestra Señora del Rosario sin ejercicio público, Hermandades dedicadas al 
ejercicio rosariano no procesional, Hermandades penitenciales de Nuestra Señora del Rosario y Hermandades o Congregaciones de Nuestra Señora de la Aurora

a) Las Hermandades de Nuestra Señora del Rosario con ejercicio público callejero surgen de las antiguas cofradías dominicas en decadencia y entre los feligreses de las parroquias que desean estructurar las salidas del Rosario público. El instituto se desarrolla en torno a la devoción estética por la imagen de la Virgen, labrándose nuevas tallas o renovándose las existentes. Las dos expresiones de culto coexisten hasta la primera mitad del XIX en que decaen los Rosarios y se comienza la celebración de la procesión anual de la imagen. A fines del XVIII o primera mitad del XIX casi todas las cofradías dominicas se configuran como hermandades diocesanas, sobre todo tras la desamortización. Hubo además que renovar las Reglas y presentarlas al Consejo de Castilla. En Sevilla fueron numerosas y muchas de ellas han llegado hasta hoy, como las de las parroquias de San Julián, Santa Catalina o Santa Ana y otras con capilla propia, como la de la Resolana o los Humeros. En Córdoba estaban las de San Andrés, Santiago, Santos Nicolás y Eulogio, el Salvador o Espíritu Santo. En Málaga, las del Sagrario, San Juan y Cristo de la Salud.

b) Las Hermandades rosarianas con otra advocación y dedicadas al ejercicio público callejero tienen su instituto primordial, o al menos importante, en la salida del Rosario público, aunque desarrollan un culto diario a su imagen titular y una Función en su festividad. Suelen tener establecida una diputación del Rosario, con autonomía respecto a la administración general de la hermandad.

En Sevilla aproximadamente pueden incluirse en este grupo 50. Muchas permanecen, aunque con un instituto de Gloria centrado en el culto y procesión a la imagen titular. Entre ellas hay que destacar a las de la Virgen de la Alegría, de San Bartolomé, Salud, de San Isidoro, Luz de San Esteban, Pura y Limpia, de la capilla del Postigo del Aceite, Amparo de la Magdalena... ${ }^{62}$

En las localidades de la Sierra de Aracena es importante la devoción a la Divina Pastora de las Almas, difundida por misioneros capuchinos. El pintor Alonso Miguel de Tovar - natural de Higuera de la Sierra- creó la iconografía de la Virgen por indicación de Fray Isidoro de Sevilla. Existen imágenes en todas las parroquias y congregaciones o hermandades -fundamentalmente de mujeres- dedicadas a su culto, y su principal instituto es el Rosario público en las tardes de domingos y festivos.

\footnotetext{
${ }^{62}$ Cfr. Mi monografía El Rosario en Sevilla: devoción... 349-387.
} 
Muy importante fueron en Córdoba la corporación del Socorro y la hermandad rosariana fundada en torno a la tercera década del siglo XVIII por el dominico lego Manuel de Ochoa junto a la portería del convento de San Pablo en torno a la devoción a la Virgen de Belén. La formaban exclusivamente pastores y desarrollaba una gran labor de caridad entre los necesitados. Este religioso fundó en esta hermandad un Rosario de mujeres, que él mismo dirigía. Adquirió ricas insignias y estableció un «Rosario de pobres» que procesionaba desde su «portal de Belén» de San Pablo hasta los lugares donde habían preparado «el caldero» o comida que a diario repartía entre ellos. En el cortejo iban los pobres con un Simpecado y distribuidos en dos coros. Este fraile murió en olor de santidad en $1761 .{ }^{63}$

c) Las Congregaciones de Nuestra Señora del Rosario dedicadas al ejercicio público callejero eran asociaciones espontáneas de vecinos y devotos para la organización y fomento del Rosario público, en parroquias, conventos o capillas, con autorización de sus titulares, y en retablos callejeros. No eran formalmente una Hermandad, al no tener presentadas Reglas para su aprobación por la Autoridad Eclesiástica.

Resulta imposible documentarlas todas, pues se fundaban de una manera muy espontánea y a veces en un mismo lugar de culto había más de una.

d) Las Hermandades de Nuestra Señora del Rosario sin ejercicio público tienen como titular a la Virgen del Rosario, celebran sus cultos cotidianos y anuales, incluso Procesión con la imagen titular, pero no rezan un Rosario público, aunque muchas procesiones solían hacer estación a sus sedes. Este proceso que afecta a la mayoría se inicia en la segunda mitad del XIX. Desde entonces se crean hermandades gloriosas del Rosario como las del barrio León de Sevilla, la del de El Palo en Málaga.

e) Las Hermandades dedicadas al ejercicio rosariano no procesional tienen como fin principal o, al menos, parte importante del instituto, el fomento de la oración del Santo Rosario entre los cofrades. Cabe citar a la congregación sevillana de los 15 Misterios del Santísimo Rosario y Caridad con los pobres enfermos de los hospitales, establecida en la capilla de Ánimas del convento de San Francisco. ${ }^{64}$

f) Las Hermandades penitenciales de Nuestra Señora del Rosario celebran recitan cultos dentro de una iglesia los Misterios Dolorosos a lo largo del año. En Semana Santa procesionan su imagen en estación de penitencia. En su instituto no figura la procesión con el Rosario público de manera

${ }^{63}$ Sobre este fraile, vid. un volumen facticio sobre frailes de la Orden en BiblioteCa Provincial DE CóRDOBA, Signatura 2104 (88)

${ }^{64}$ Idem, pp. 401-402.

Hispania Sacra, LXII

126, julio-diciembre 2010, 621-659, ISSN: 0018-215-X 
permanente. Muchas corporaciones rosarianas de gloria se han fusionado con hermandades de penitencia en la época contemporánea y otras han surgido en el siglo XX y XXI. Nos limitamos a las de las capitales de provincia.

En Sevilla está establecida en la capilla del antiguo colegio dominico de Monte Sión, dedicada al Misterio de la Oración en el Huerto. Desde su fundación en el siglo XVI, realiza la estación de penitencia el Jueves Santo. Recientemente se ha creado otra en el Polígono de San Pablo. En la provincia pueden citarse las de Alcalá de Guadaira, Santiponce o asociaciones parroquiales como las de Camas o Gerena.

En Granada la Archicofradía primitiva está unida a las Tres Caídas, cofradía de penitencia. Lo mismo ocurre con la de N.P. Jesús del Perdón y Nuestra Señora de la Aurora, cuyo origen es una congregación del rosario de la aurora.

En Córdoba, en el convento de San Pablo, está la cofradía de la Expiración, que tiene como titular Dolorosa a la Virgen del Rosario, pero ya ninguna relación con la antigua corporación dominica.

En Málaga la Cofradía de los Dolores del Puente tiene su origen en uno de los primeros rosarios públicos. En la iglesia de la hermandad de la Aurora María se fundó en 1929 la cofradía penitencial de la Sentencia y Nuestra Señora del Rosario.

En Cádiz la Archicofradía de la Palma nació del primer rosario que fundara Fray Pablo y hoy está fusionada a una cofradía de penitencia, lo mismo que la popular cofradía de las Angustias «El Caminito» fue en su origen una hermandad rosariana dedicada al uso público. La cofradía de penitencia del Perdón, tiene una imagen mariana del Rosario en sus Misterios Dolorosos y data de 1935.

En Almería, la Virgen del Rosario del Mar, asociación penitencial fundada recientemente.

En la ciudad de Huelva existe desde 1948 la Cofradía de la Sagrada Cena, Cristo del Amor y Nuestra Señora del Rosario.

En Jaén está erigida desde 1984 la Hermandad del Rosario y Cofradía del Señor de la Pasión Despojado de sus Vestiduras y Nuestra Señora de la Amargura.

g) Las Hermandades o Congregaciones de Nuestra Señora de la Aurora formalmente no se denominan del Rosario, pero estas hermandades o congregaciones se erigen desde fines del siglo XVII con el instituto fundamental del Rosario público de madrugada, sobre todo los días festivos, con celebración de la misa de alba. En Sevilla hay una hermandad en la iglesia de Santa Marina y varias en los pueblos de la provincia: Arahal, 
Estepa, Fuentes de Andalucía, Lebrija, Morón de la Frontera o Los Palacios.

En Córdoba está la de la ermita de la calle Feria y otras muchas en la provincia: Montilla, Priego, Aguilar de la Frontera...

En Granada, desde fines del XVI, hay una hermandad en el convento de San Gregorio Bético. En las primeras décadas del XVIII aparecen en Motril (1717) o Albuñol (1719)

En Málaga está la ya Hermandad de la Aurora María fundada quizá antes de 1690 como rosario escolar y otra en Ronda. En Tabernas (Almería) hay una hermandad de la Aurora, cuyas Reglas se aprueban en 1704, dedicada al rezo del Rosario en sufragio de las ánimas. Salía en procesión los domingos y viernes, realizando en cuaresma la vía sacra. Era una hermandad numeraria como las cofradías. ${ }^{65}$

En general estas hermandades se hallan en ermitas o capillas y son la expresión más popular de la devoción en contraposición con la Cofradía del Rosario u otras congregaciones de Rosario de prima de la iglesia parroquial de la localidad. En Morón de la Frontera fue fundada en 1692, a iniciativa de los propios vecinos, especialmente los más humildes y con el apoyo explícito del prelado Jaime de Palafox, que impuso su autoridad ante el clero parroquial. ${ }^{66}$

En Arjonilla (Jaén) hubo una pugna entre la cofradía parroquial y la denominada «soldadesca del Santo Rosario» en la ermita de San Roque. Aunque no se denomine de la Aurora, es un caso significativo que manifiesta una cierta marginalidad de estas corporaciones. ${ }^{67}$

Cabe aplicar esta tipología a cualquier localidad andaluza, pues el se trata de fenómeno de características comunes, pues las diferencias son de escasa relevancia.

\section{LAS COPLAS DE LOS ROSARIOS}

Las Coplas de los Rosarios de la Aurora se remontan a los años finales del siglo XVII. Adquieren su perfil en los siglos XIX y primer tercio del XX con

\footnotetext{
${ }^{65} \mathrm{M}^{\mathrm{a}}$ Desamparados MARTínez SAMPEDRO, «Las cofradías de Tabernas» en José RuIZ FernándeZ y Valeriano SÁNCHEZ Ramos (coords.), Actas de las primeras jornadas de religiosidad popular, Almería 1998, pp. 243-252.

66 Vid mi artículo «Los espacios de poder religioso entre clero y religiosidad popular. El Rosario de la Aurora de Morón a comienzos del siglo XVIII» en Revista de Humanidades, $\mathrm{n}^{\circ}$ 8, Sevilla, Centro Asociado de la UNED, 1997, pp. 105-117.

${ }^{67}$ Ildefonso RUEDA JÁNDULA, 407-415.
} 
las denominadas de campanillas o campanilleros. ${ }^{68}$ Antes en los cortejos había un cantor que entonaba las coplas. Lo acompañaban los devotos y un coro infantil para las avemarías. Se tocaban violines, oboes, bajón... desde 1691. Inicialmente hubo controversia, pues algunos concebían su inclusión como irreverencia. ${ }^{69}$

Las primeras coplas eran estrofas breves y muy sencillas y derivan de las saetas que los predicadores entonaban en las Misiones. Por ejemplo, en Pedrera se mantenía en la Novena de Ánimas la expresión de «Saetas del Rosario»:
«Por los cofrades difuntos/ de esta santa cofradía, / cristianos: dadme limosna/ que os la premiará María»
«Benditos sean de Dios/ los que dan limosnal para librar los cofrades/ y que vayan a la gloria»
«Afligidos en la cárcel/ de la Divina Clemencia/ se hallan todos aquellos/ que espe- ran las indulgencias»
«Vuestros padres angustiados/ claman desde el Purgatorio:/ hijos de mi corazón,/ ¿no me váis a dar socorro?».70

En la segunda mitad del XVIII y sobre todo en el XIX se canoniza la ya existente estrofa de siete versos, formada por una cuarteta cuyos versos primero y tercero son decasílabos y el segundo y cuarto asonantados, dodecasílabos. Y enlazando con la cuarteta había un estribillo o saetilla, de tres versos, el primero de seis sílabas, el segundo, de diez, y el tercero de doce, asonantados igualmente con el último de la cuarteta el primero y tercero de éste.

El profesor Peláez del Rosal, siguiendo los estudios de Cruz Casado, remonta su origen a unas endechas del montillano Enríquez de Arana, fallecido en $1735 . .^{71}$

Hay que distinguir las coplas propiamente del Rosario, que glosaban los Misterios, se referían a alguna festividad especial o bien a las ánimas en noviembre, y también de «las campanillas» tocadas por los «avisadores» para

\footnotetext{
${ }^{68}$ Sobre las Coplas de Aurora en la provincia de Sevilla, vid. mi reciente monografía El Rosario de la Aurora y sus coplas. Tradición y religiosidad en Sevilla y su provincia, Sevilla, 2007.

${ }^{69} \mathrm{El}$ padre dominico Antonio de Cáceres, en un célebre sermón, se hace eco de estas críticas a los instrumentos, saliendo en defensa de ellos, afirmando que a algunos les mueve más a devoción el Rosario con los instrumentos «para que salgan con más dulzura las voces» y que en todo caso cualquier forma de rezar el Rosario es válida y agradable a Dios y, por tanto, todas ellas ganan las indulgencias concedidas. Cfr. Oración a las rogativas que por la sucesión deseada de nuestros... Monarcas hizo la Ilustre Parroquia del Sagrario... El Sermón tuvo lugar el 29 de abril de 1691. Impreso de la Biblioteca Universitaria de Sevilla 112/123.

70 Archivo Parroquial de Pedrera, Libro de actas y cuentas de la Cofradía del Rosario. 1764. Se insertan tras los estatutos de la corporación. El libro está sin foliar.

${ }^{71}$ Manuel PeláEz Del Rosal, «Algunos aspectos formales de los rosarios públicos en Andalucía: el caso de Priego de Córdoba en el siglo XVIII» en H. Paz Castaño y C. Romero MensaQue, 399-406.
} 
convocar al vecindario al Santo Rosario y solicitar limosnas. De estos segundos derivan los muy numerosos Coros de Auroros y Campanilleros que se crearon en todas las provincias andaluzas.

Modesto García Jiménez distingue entre auroros y campanilleros. Los auroros conservan más el estilo antiguo de las coplas, con tonada más lenta, y utilizan muy pocos instrumentos, esquila, campanillas, guitarras, laúdes... Los campanilleros entonan las coplas con tonadas más vivas y ligeras y utilizan muchos más instrumentos: panderetas, tambor, botellas de anís, triángulos e incluso saxofones, entre otros. En Aznalcázar (Sevilla), por ejemplo, se distingue por parte del coro «Santiago Apóstol» entre tonos mayores (alegres, vivos), menores (lentos, «tristes») e incluso flamencos.

a) «Las Campanitas»y «Los Campanilleros» marchaban primero por las calles que debía recorrer el Rosario haciendo sonar los instrumentos. Posteriormente quizá entonando saetas o jaculatorias y finalmente cantando coplas. En algunos casos se contrataba un clarinero. La finalidad era anunciar a los vecinos el comienzo del Rosario, animarlos a participar y prevenirlos de las consecuencias nefastas para sus almas si no lo hacían.

En tu puerta están la campanilla, l levanta cristiano si la quieres ver/ porque dicen que viene la Aurora / Repartiendo rosas al amanecer./ Vamos a coger/ a la rosa más grande y hermosal que sembró María contra Lucifer (Coro de campanilleros de Castilleja). ${ }^{72}$

Son las cuentas del Santo Rosario/ balas que tiran al lobo infernal/que acomete a todos furioso/a a todas las almas quiere devorar/ $Y$ así rezarás/con las cuentas las avemarías/que son armas fuertes para pelear. (Aurora de Ronda).

b) Desde finales del XVII se documentan ya coplas propias para cada Misterio, con breves estrofas y alto contenido teológico. En la segunda mitad del XIX, al reestructurarse el Rosario público con las procesiones de la Aurora, las mujeres entonan estas coplas, creándose modelos muy populares como los que reproducimos y que aún siguen vigentes en muchas localidades andaluzas y fueron compuestos por el canónigo Muñoz y Pabón.

\section{Primer misterio gozoso}

Enviado por Dios desde el cielo,/desciende a la Virgen el Ángel Gabriel /,a anunciarle que madre sería /del Dios de sus Padres, del Dios de Israel;/ y al

\footnotetext{
${ }^{72}$ Letra facilitada por Salvador Naranjo González-Pola, gran estudioso de las coplas. Pertenecen al Coro de Campanilleros de la Hermandad de la Virgen de la Soledad de Castilleja de la Cuesta.

Hispania Sacra, LXII

126, julio-diciembre 2010, 621-659, ISSN: 0018-215-X
} 
ella acceder/ en sus puras y augustas entrañas/ el verbo del Padre vistió humano ser.

\section{Primer misterio doloroso}

Jesucristo, triste y abatido/ se dirige al Huerto de Getsemani;/ y pensando en mis ingratitudes,/llora y suda sangre de tanto sufrir./AApartad de mí!/este cáliz, suplica a su Padre,/ mas si tú lo quieres, yo quiero morir.

\section{Primer misterio glorioso}

Jesucristo, triunfante y glorioso/ del sepulcro sale vestido de sol,/ y sus guardias rodaron por tierra,/ rindiéndole el culto de la adoración./;Porque padeció!/ lo circunda la gloria del Padrel pues la gloria es premio de la humillación.

c) Las Coplas dedicadas a la Virgen loan dedicadas sus virtudes, privilegios y cualidades, referidas a la imagen titular de la hermandad o congregación, a alguna festividad significativa, sobre todo la Inmaculada. estas son de Aguilar con los tres últimos versos siempre comunes:

De tus dones no hay mujer ningunal Fuiste hija, madre, esposa de Dios/ A tus plantas se postra la luna, / te vistes de estrellas, te corona el soll Digo y es verdad (bis)/ que las piedras se vuelven brillantes/ por donde la Aurora tenga que pasar. ${ }^{73}$

d) Las Coplas de Ánimas, muchas concebidas para cantarlas por las calles en noviembre durante el Rosario de la Aurora, son vivos y expresivos exponentes de una religiosidad popular, vivencia trascendente e inmanente de una actitud ante la vida y la muerte y recuerdo emotivo de los difuntos, que, gracias al Rosario, se hacen de alguna manera presente en una dimensión viva y espiritual con los vivos. Estos Rosarios de Ánimas y sus coplas eran organizados fundamentalmente por hermandades y congregaciones rosarianas o de ánimas. Hoy están vigentes en la provinvia de Sevilla, en Castilleja de la Cuesta, con los campanilleros de la Hermandad de la Soledad y en Mairena del Alcor por la de las Ánimas Benditas.

El sonido de las campanillas/ y nuestros clamores testigos serán/ de que hacéis por las benditas almas/ todo cuanto ellas puedan desear./ Y el Señor dirá,/

\footnotetext{
${ }^{73}$ Debo la letra de estas coplas a la gentileza del investigador José Galisteo Martínez.
} 
Padre mío por estos devotos/ ya nos vemos libres de tanto penar.(Coplas de Mairena del Alcor. Hermandad de Ánimas). ${ }^{74}$

e) Había otras coplas para los tiempos litúrgicos: navidad, cuaresma, ... o que enunciaban diversos temas teológicos.

Desde el cielo bajó una palomal y en el santo templo la vieron volar, / y en el pico dicen que llevabal las cincuenta rosas del Santo Rosal./ Venid a alabar/ a la Reina que es de Cielos y Tierra, / la Fuente de Gracia, nuestra Eterna Paz. (Auroros de Gilena). ${ }^{75}$

Hoy sólo la Hermandad del Rosario de los Humeros tiene instituido un coro de estas características en la ciudad de Sevilla. En la provincia se conserva activa en Aznalcázar, Castilleja de la Cuesta, Bormujos, Gilena, Lebrija, Mairena del Alcor, Los Palacios, Puebla de Cazalla, Tomares, Viso del Alcor... entre otras localidades.

En las demás provincias de Andalucía están muy extendidas las coplas de la aurora, sobre todo en la provincia de Córdoba. Una de las localidades que con más interés cuidan del mantenimiento de esta tradición es, sin duda, la de Priego con la Hermandad de Nuestra Señora de la Aurora, con sede canónica en la pequeña, pero magnífica capilla propia y que desarrolla muchas actividades en pro de la investigación de las Coplas tradicionales, habiendo publicado ya dos libros recopilativos y varios artículos en su revista «Aurora». ${ }^{76}$ Otras localidades bien significativas son: Aguilar, Benamejí, Castro del Río, Iznájar, Lucena, Luque, Montilla, Monturque, Puente Genil y Rute.

En Riotinto (Huelva) conservan la llamada «esquila» o copla de campanilleros del Rosario de la aurora, cuya memoria se remonta a 1883, pero existía antes una tradición rosariana en la comarca, sobre todo en Zalamea la Real y sus aldeas, con coplas de gran pureza musical, y La Corte de Santa Ana. ${ }^{77}$ Suelen cantarse durante las madrugadas de la Novena de octubre. En la actualidad, la Virgen del Rosario es Patrona y Alcaldesa perpetua de Riotinto. En Aracena, los grupos de campanilleros cantan coplas en las madrugadas de los domingos de octubre, previas al Rosario de la Aurora y el último domingo del mes se celebra misa de campanilleros en la iglesia prioral del Castillo. También hay que

\footnotetext{
${ }^{74}$ Letra facilitada por Eusebio Pérez Puerto, que fue Hermano Mayor de esta Hermandad.

75 Vid. El repertorio en un interesante librito de Miguel Ángel López Pardo El Rosario de la Aurora, col. Raigambres, Gilena, 1982.

${ }^{76}$ El más importante y pionero, M. Peláez del Rosal, y R. JimÉnez Pedrajas, Cancionero Popular del Rosario de la Aurora, Priego, 1978

${ }^{77}$ En esta pequeña aldea del municipio de Santa Ana, las mujeres cantan una Novena de calle en las madrugadas previas a la festividad del Rosario y también en agosto para que puedan asistir la población que hubo de emigrar y en estos días regresan para estar con la familia.
} 
destacar los campanilleros de Galaroza. En otra zona de la provincia destacan la tradición del rosario y sus coplas en Bollullos Par del Condado.

En Jaén hay interesantes repertorios de coplas en Campillo de Arenas, Carchalejo, en ambos durante las fiestas de moros y cristianos, Noalejo, Cambil o Mancha Real donde se llamaban «moniduras» a las «despiertas» de la aurora. ${ }^{78}$

En Granada están Galera y Gójar. En aquella recientemente se han recuperado las coplas de la aurora por los hermanos del Rosario en la madrugada del 15 de agosto y en el mes de octubre. En Gójar se cantan en las fiestas de la Divina Pastora.

En Ronda, Málaga, existe la Hermandad de la Aurora y sus auroreros que cantan por las calles coplas una vez al mes de madrugada. Hay que citar en la misma serranía a los auroreros de Arriate.

En Fiñana, Almería, existe una Hermandad de la Virgen de la Aurora, surgida en el siglo XIX y fusionada con una Cofradía del Rosario, que ya existía a fines del XVI. Hay tradición de Rosarios de aurora en Albanchez y Chirivel, donde el 24 de agosto se entonan coplas del rosario.

\section{LA INFLUENCIA ANDALUZA EN AMÉRICA. LOS PRIMEROS ROSARIOS Y LAS COPLAS DEL SEVILLANo CRISTÓBAL DE AgUILAR}

Ya pudimos constatar como en la segunda mitad del XVII aparecen en las colonias americanas claros precedentes de los Rosarios públicos. No obstante, es claro que el instituto formal proviene de la metrópoli y más concretamente de Andalucía y la población asume este origen. En otro folleto de la serie rosariana de Martín de Braones, concretamente la «Noticia quinta del estado y progreso que tiene dentro y fuera de la muy noble y muy leal ciudad de Sevilla la devoción del Santísimo Rosario...» fechada en 1693 (Martín de Braones, 1693) se da noticia de la extensión de los Rosarios públicos en la ciudad de Méjico y, sobre todo, en Lima, recogiendo diversas noticias manuscritas procedentes de allí y cuyo tenor es el siguiente:

«Aviendo llegado a esta ciudad de Lima unas relaciones impresas, que expresaban la fervorosa devoción con que se reza en Sevilla el Rosario, y que a prima noche y de madrugada andan cantándolo a coros por las calles muchas comunidades compuestas de niños y hombres de todas calidades Pueblo, Nobleza y Clero, quisieron en esta ciudad imitar su devoción, dando principio a tan devotos actos la víspera de la solemnísima fiesta de la Concepción de nuestra Señora del próximo año pasado de 1691 y se prodigaron por toda la Octava, saliendo muchos Rosarios de diferentes Parroquias y Conventos, assí

${ }^{78}$ Luis CoRONAS TeJADA, op. cit. 
de Monjas, como de Frayles, manifestando esta Ciudad su riqueza y majestad tanto en el número de hachas que sacaba cada Rosario y costosísimas invenciones de requisíssimos Faroles, en que se vían los atributos de N. Señora, quanto en el Carro triunfal en que cada Rosario llevaba colocada la Imagen de la Reyna de los Ángeles: aviendo avido Carro de estos, que pudo competir, sino excedió, al que en Sevilla se sacó en la fiesta de la Victoria de Viena; y la emulación con que los Rosarios se competían huviera proseguido hasta el día de oy si el Illustríssimo y Excellentísssimo Señor D. Melchor de Liñán y Cisneros, Arçobispo de esta Ciudad, y Virrey que ha sido de este Reyno, mirando la conservación de devoción tan fructuosa, no hubiera prohibido tan excesivos gastos, diciendo que por la solemnidad de la fiesta de la Concepción los avía permitido, pero que en adelante se rezasse el Rosario con Faroles ordinarios, escusándose todo género de gasto particular; en cuya conformidad se prosigue con grande consuelo de toda esta Ciudad, aviéndose observado que desde que se reza el Rosario por las calles han cessado los temblores de tierra tan continuos en este Reyno». ${ }^{79}$

Desde Andalucía se difundió extraordinariamente también el Rosario de la Aurora y sus coplas por la América española, dimensión ésta muy poco estudiada y sin duda importante. Reproduzco algunas coplas compuestas por un ilustre sevillano, Cristóbal de Aguilar, que se afincó en Córdoba (Argentina) en 1750 hasta su muerte en 1828. Fue hermano de la Cofradía de españoles de la localidad e incluso Diputado de demandas. ${ }^{80}$

En Córdoba había dos Cofradías del Rosario, la de españoles y la de naturales. De la de españoles que en 1790 se fusionó con una congregación del Rosario de la Aurora, también de españoles, que se dedicaba a este uso y de la que era integrante el sevillano Aguilar, estableciéndose que todos los domingos saldría de madrugada, el cortejo a la calles acompañados por la imagen de la Virgen sobre andas y a su finalización se diría en el convento de Santo Domingo la misa de alba por la comunidad. Este dato nos confirma cómo la Orden favorecía y controlaba esta devoción, la hacía propia y la colocaba en el propio instituto de la Cofradía.

79 Alonso MaRTín de BRAOnEs, Noticia quinta del estado y progresso que tiene dentro y fuera de la Muy Noble y muy Leal Ciudad de Sevilla la devoción del Santísimo Rosario de la siempre Virgen María. Sevilla, 1693 . S/p.

${ }^{80}$ Ana Martínez de Sánchez ha escrito varios trabajos sobre el Rosario en Córdoba, por ejemplo, «Cofradía de Nuestra Señora del Rosario de españoles en Córdoba del Tucumán», en XI Congreso Nacional y Regional de Historia Argentina, Academia Nacional de la Historia, Buenos Aires, 2001. Las Coplas de Aguilar «Versos para recordar al Rosario de la Aurora» y unas pinceladas biográficas en la Biblioteca de Autores Españoles, tomos 299 y 300, editada por Atlas en Madrid en 1989. Las coplas en el tomo 300, pp. 317-321. Cristóbal de Aguilar nació en Sevilla en torno a 1733 y fue bautizado en la parroquia del Sagrario. Un análisis específico de estas coplas comparándolas con las andaluzas en mi artículo «Religiosidad dominica sevillana y colonial en Córdoba (Argentina) a fines de la Edad Moderna. Las Coplas del Rosario de la Aurora de Cristóbal de Aguilar», en Segundas Jornadas de Historia de la Orden Dominicana en la Argentina. Actas, Tucumán, Universidad Santo Tomás de Aquino, 2006, pp. 317-334.

Hispania Sacra, LXII

126, julio-diciembre 2010, 621-659, ISSN: 0018-215-X 
Ofrezco a continuación algunas Coplas por él compuestas y que seguramente él mismo cantaría en su congregación y Cofradía del Rosario:

«El lucero con sus resplandores/ anuncia que el alba no tarda en llegar,/ desterrando tinieblas oscuras/ y llenando al mundo de felicidad:/ venid a admirar/ la presteza con que huyen las sombras/ cediendo su imperio a la claridad»

«Por un poco de sueño que quites/ a tu cuerpo ahora, lograrás después/ un descanso que nunca se acabe:/ no quieras por flojo tal dicha perder./ Bien puedes creer/ a María, que es madre del Verbo/ y nos ruega ahora para nuestro bien».

Y esta otra copla que compone en homenaje a las cantoras y cantores de los Rosarios:

«Vuestras voces alegran la tierra,/ al cielo dan gozo y al infierno horror,/ cuando unidos en coro cantáis/ del Arcángel santo la salutación./ ¿Qué empleo mayor/ que ocuparte en lo que al cielo agrada/ y al demonio llena de rabia y furor».

Aguilar era un cofrade comprometido que trata de evangelizar a través del Rosario las masas populares, con letras como estas que encierran alta teología:

«Si al que ama nada le es difícil/ por el dulce objeto de su estimación, / ¿cómo amando a María de veras/ te muestras tan tibio en su devoción?/ Mira que el amor/ que en las obras no se manifiesta/ es amor bastardo, es pura ilusión». 